\title{
THE ROLE OF INSTITUTIONS IN SHAPING GEOGRAPHY OF DEVELOPMENT DISPARITIES ACROSS EUROPEAN UNION
}

\author{
Mindaugas Butkus*, Alma Mačiulytė-Šniukienė*, Kristina Matuzevičiūtė* \\ * Šiauliai University, Institute of Regional Development, Visinskio str. 25-118, Siauliai, Lithuania, \\ mindaugo.butkaus@gmail.com, alma.m@splius.lt, matuzeviciute@gmail.com
}

\begin{abstract}
The role of institutions in shaping geography of development disparities across European Union

Assessing the effect of regional financial support provided by the European Union (EU), research examines whether support promotes growth, increases productivity and creates new jobs. Scientific studies rarely discuss the effect of support in the light of the geography of development disparities despite the fact that cohesion is the ultimate goal of the EU's regional policy. Moreover, previous contributions show the importance of factors that condition the effect of support, thus raising the question of the heterogeneity of effects across regions. In the light of these facts, this paper aims to propose a model that supplements a new strand of literature based on a quasiexperimental approach and to assess the effect of support on territorial disparities capturing its heterogeneity. An empirical application is based on NUTS 3 level data over the $2000-2006$ programming period (PP) and an estimation of the effects on the dynamics of disparities between support beneficiaries and developed regions. Results show that support diminishes disparities and that the significance and size of the effect are highly conditioned on the institutional quality in the region.
\end{abstract}

Key words: difference-in-differences estimator, Structural Funds, Cohesion Policy, regional disparities, institutional quality, NUTS 3, European Union

\section{INTRODUCTION}

The impact of Cohesion Policy (CP) has become a subject of intense academic and policy debate since its effects remain controversial. Despite the fact that the ultimate goal of the EU's CP for 2000 - 2006 and 2007 - 2013 PPs was to diminish existing geographical disparities in terms of development level, only few studies (Boldrin and Canova 2001, Beugelsdijk and Eijffinger 2005, Ederveen et al. 2006, Eggert et al. 2007, Llussá and Lopes 2011, Kyriacou and Roca-Sagalés 2012, Maynou et al. 2016, Eberle and Brenner 2016 and Piętak 2018) analyze the effects of Structural funds' (SF) payments in the light of this problem. Studies do not agree whether SF payments contributed to shaping the geography of development in the EU and diminished territorial disparities.

Effects of SF payments are mainly evaluated on the NUTS 1 and 2 levels, except Soukiazis and Antunes (2006), Falk and Sinabell (2009), Becker et al. (2010 and 2012), Fratesi and Perucca (2014), Tsionas et al. (2014), Gagliardi and Percoco (2017) who targets NUTS 3 regions. However, research by Bourdin (2015), Hegerty (2016) and Butkus et al. (2018), decomposing territorial disparities in the EU, show that the problems have now started to occur on the NUTS 3 level. The possible reason is that CP in the EU is mainly focused on the NUTS 2 and does not deal sufficiently enough with the problems within the NUTS 2 regions, i.e. on the NUTS 3 level. 
According to the European Commissions' (EC) 7th report on economic, social and territorial cohesion (2017), in order to use SF payments effectively, the supported countries must be characterized by improving the quality of government, implementing structural reforms and strengthening the administrative capacity that is conducive for economic growth. Therefore, evaluating the effect of SF payments it has also becomes crucial to take into account institutional quality.

Our research in this paper aims to: 1) assess the effect of SF payments on territorial disparities by developing a model on the basis of a quasi-experimental strategy; 2) augment the model to examine the heterogeneous effects of SF payments conditioned by institutional quality; and 3) analyze the effect of regional SF payments over 2000 - 2006 on regional disparities on the NUTS 3 disaggregation level.

\section{LITERATURE REVIEW}

Three econometric approaches are commonly used to analyse the effects of SF payments. The traditional one is based on a panel/cross-sectional methodology (for the summary of studies see Tab. 1). The main advantage is that this approach uses statistical hypothesis straightforward for identifying CP's effects. Further, it can incorporate various conditional factors that help to explain the heterogeneity of the effects. Nevertheless, these methods have several constraints. First, the underestimation of the effectiveness of SF payments is related to the biased estimates caused by reverse causality. The second problem occurs because of the unobserved heterogeneity, which is caused by unobserved variables, or omitted variables due to data availability.

The second strand of the research applies spatial econometric techniques (for the summary of studies see Tab. 2) allowing us to avoid an assumption that regions are isolated from their neighbours (Le Gallo et al. 2011). It includes two main aspects: 1) spatial dependence between the regions and 2) spatial heterogeneity in the relationships. The regional spillover effects are also considered in this approach. Nevertheless, it still has one weak point: the parameters of spatial dependence are very simple in comparison to the complex trade, capital and people flows actually taking place between regions.

Looking for more rigorous empirical evidence on the effects of SF payments, a recent contribution has adopted research strategies which are based on quasiexperimental conditions and counterfactual comparisons (for the summary of studies see Tab. 3). The commonly applied evaluation method is natural or quasiexperiment. Here a financial intervention itself is assumed as an experiment, and the strength of the method hinges on finding the best possible naturally emerging contrast group that could imitate properties of the control group (Blundell et al. 1998).

In the vast majority of studies (see Tabs. $1-3$ ), regional growth is used as an outcome variable, following employment and productivity. There are only a few studies analysing the impact of SF payments on regional disparities and while some (Beugelsdijk and Eijffinger 2005, Eggert et al. 2007, Llussá and Lopes 2011, Maynou et al. 2016, Kyriacou and Roca-Sagalés 2012, Eberle and Brenner 2016) show a positive impact, others (Boldrin and Canova 2001, Ederveen et al. 2006, Piętak 2018) do not confirm any effect. 
Tab. 1. Main results of previous literature on SF effects applying methods of cross sectional / panel data

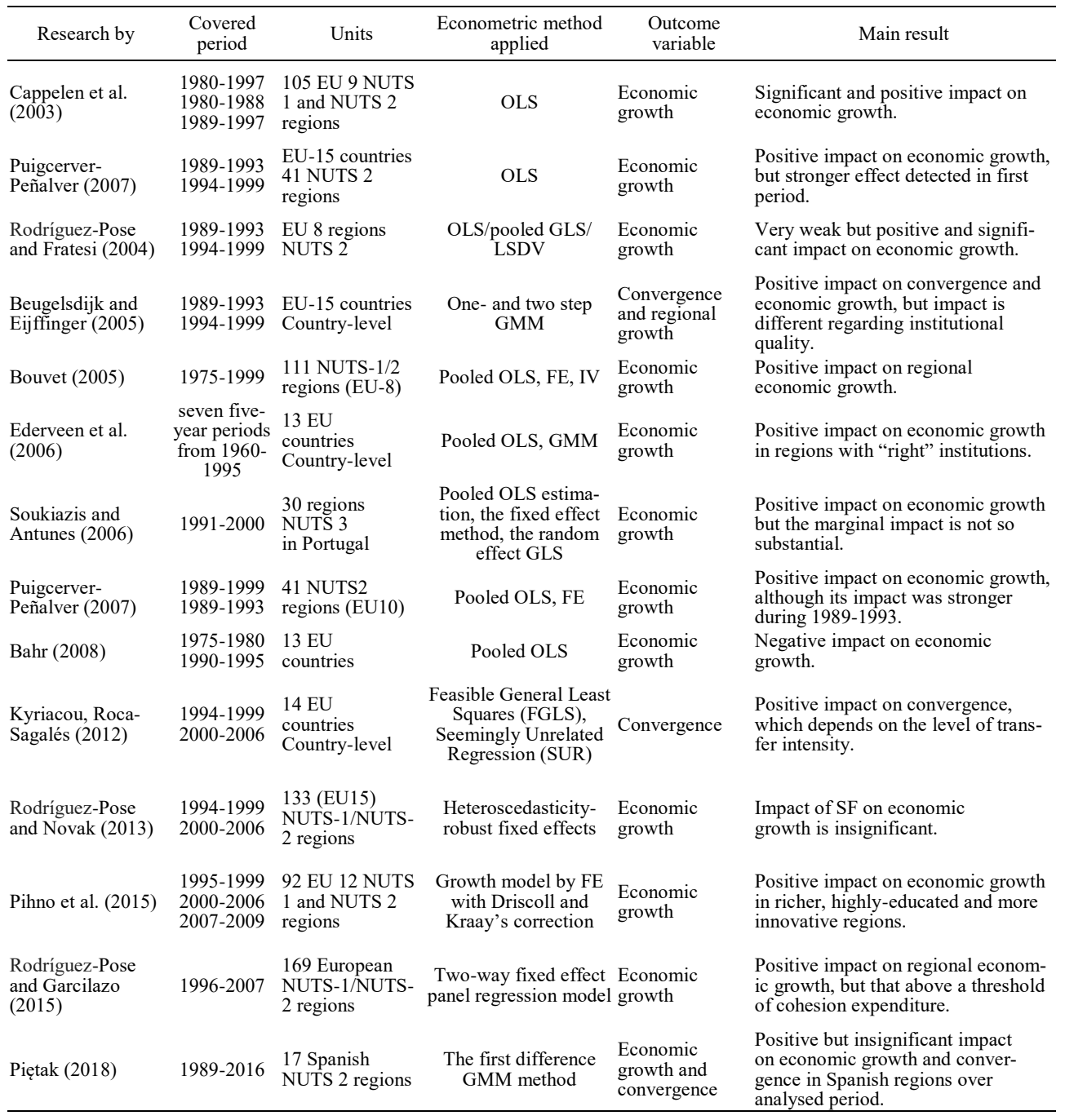

Despite CP's outcome under consideration, the results of previous contributions are ambiguous. Research by Cappelen et al. (2003), Bussoletti and Esposti (2004), Bahr (2008) and Becker et al. (2012) among many others conclude that SF payments had a positive effect. There are also studies (for example, Garcia-Milà and McGuire 2001 and Dall'erba and Le Gallo 2008) which found that SF transfers had none or even a negative (Boldrin and Canova 2001 and Dall'erba et al. 2009) effect. Potential sources causing these ambiguous results include the application of different methods, data variations in terms of the analysed period, the NUTS level and countries/regions covered by the analysis, as well as conditioning factors that 
were assessed. Considering the latter, studies by Rodríguez-Pose and Fratesi (2004), Mohl and Hagen (2010), Becker et al. (2013), Bouayad-Agha et al. (2013), Rodríguez-Pose and Garcilazo (2015) and Crescenzi and Giua (2016) revealed that the effect of SF payments is positive just if certain conditions are met.

Tab. 2. Main results of previous literature on SF effects applying methods of spatial econometrics

\begin{tabular}{|c|c|c|c|c|c|}
\hline Research by & $\begin{array}{l}\text { Covered } \\
\text { period }\end{array}$ & Units & $\begin{array}{l}\text { Econometric meth- } \\
\text { od applied }\end{array}$ & $\begin{array}{l}\text { Outcome varia- } \\
\text { ble }\end{array}$ & Main result \\
\hline $\begin{array}{l}\text { Dall'erba and Le } \\
\text { Gallo (2004) }\end{array}$ & 1989-1999 & $\begin{array}{l}145 \text { NUTS-2 } \\
\text { regions (EU-12) }\end{array}$ & $\begin{array}{l}\text { Spatial weight } \\
\text { matrices, OLS } \\
\text { estimation of the } \\
\text { absolute } \beta \text { - } \\
\text { conditional conver- } \\
\text { gence model; GL, } \\
\text { GMM estimator }\end{array}$ & $\begin{array}{l}\text { Economic and } \\
\text { employment } \\
\text { growth }\end{array}$ & $\begin{array}{l}\text { No significant impact on economic or } \\
\text { employment growth. In some cases, the } \\
\text { impact of individual funds (Obj. } 1,3 \text { and } \\
\text { 4) has been statistically significant, but } \\
\text { pretty low or, sometimes negative. }\end{array}$ \\
\hline $\begin{array}{l}\text { Dall'erba and Le } \\
\text { Gallo (2008) }\end{array}$ & 1989-1999 & $\begin{array}{l}145 \text { NUTS-2 } \\
\text { regions of (EU- } \\
12)\end{array}$ & $\begin{array}{l}\text { Spatial lag model } \\
\text { with IV }\end{array}$ & $\begin{array}{l}\text { Economic } \\
\text { growth }\end{array}$ & $\begin{array}{l}\text { Positive impact on economic growth, but } \\
\text { spillover effects are very small in periph- } \\
\text { eral regions. }\end{array}$ \\
\hline $\begin{array}{l}\text { Falk and Sinabell } \\
(2009)\end{array}$ & $1995-2004$ & $\begin{array}{l}1084 \text { NUTS-3 } \\
\text { regions (EU-15) }\end{array}$ & $\begin{array}{l}\text { Spatial economet- } \\
\text { rics, pooled OLS, } \\
\text { median regression } \\
\text { approach, weighted } \\
\text { least squares }\end{array}$ & $\begin{array}{l}\text { Economic } \\
\text { growth }\end{array}$ & $\begin{array}{l}\text { Positive and significant impact on } \\
\text { economic growth. Obj. } 2 \text { and } 3 \text { payments } \\
\text { impact is negative. }\end{array}$ \\
\hline $\begin{array}{l}\text { Mohl and Hagen } \\
(2008)\end{array}$ & 1995-2005 & $\begin{array}{l}124 \text { NUTS-1 / } \\
\text { NUTS-2 regions }\end{array}$ & $\begin{array}{l}\text { Panel: Least Square } \\
\text { Dummy Variable } \\
\text { estimator (LSDV), } \\
\text { GMM, spatial corre- } \\
\text { lation }\end{array}$ & $\begin{array}{l}\text { Economic } \\
\text { growth }\end{array}$ & $\begin{array}{l}\text { Positive and significant impact on } \\
\text { economic growth. Obj. } 2 \text { and } 3 \text { payments } \\
\text { impact is negative. }\end{array}$ \\
\hline $\begin{array}{l}\text { Dall'Erba et al. } \\
(2009)\end{array}$ & 1989- 1999 & $\begin{array}{l}145 \text { NUTS-2 } \\
\text { regions (EU 12) }\end{array}$ & OLS estimation & $\begin{array}{l}\text { Productivity } \\
\text { growth }\end{array}$ & $\begin{array}{l}\text { Significant, but always negative and } \\
\text { very small impact on productivity } \\
\text { growth. }\end{array}$ \\
\hline $\begin{array}{l}\text { Mohl and Hagen } \\
(2010)\end{array}$ & $2000-2006$ & $\begin{array}{l}126 \text { NUTS-1/ } \\
\text { NUTS-2 regions } \\
\text { (EU-6) }\end{array}$ & $\begin{array}{l}\text { Spatial econometric } \\
\text { estimator, GMM } \\
\text { estimator }\end{array}$ & $\begin{array}{l}\text { Economic } \\
\text { growth }\end{array}$ & $\begin{array}{l}\text { Positive and statistically significant } \\
\text { impact on the economic growth. Region- } \\
\text { al spillovers have a significant impact on } \\
\text { the regional growth rates irrespective of } \\
\text { which Objective and time lag is ana- } \\
\text { lysed. }\end{array}$ \\
\hline $\begin{array}{l}\text { Le Gallo et al. } \\
(2011)\end{array}$ & 1989-1999 & $\begin{array}{l}145 \text { NUTS-2 } \\
\text { regions (EU-12) }\end{array}$ & $\begin{array}{l}\text { Cross-section: Spa- } \\
\text { tial lag model with } \\
\text { global and local } \\
\text { Bayesian spatial } \\
\text { method (MCMC) }\end{array}$ & $\begin{array}{l}\text { Economic } \\
\text { growth }\end{array}$ & $\begin{array}{l}\text { Weak impact on the economic growth, } \\
\text { but local impact is very diverse, with } \\
\text { a positive influence on the growth } \\
\text { of British, Greek, and southern Italian } \\
\text { regions. }\end{array}$ \\
\hline $\begin{array}{l}\text { Fratesi and Perucca } \\
(2014)\end{array}$ & 2006-2010 & $\begin{array}{l}108 \text { NUTS- } 3 \\
\text { regions of CEE }\end{array}$ & $\begin{array}{l}\text { Cross section regres- } \\
\text { sion model, OLS, } \\
\text { spatial regression } \\
\text { model }\end{array}$ & $\begin{array}{l}\text { Economic } \\
\text { growth }\end{array}$ & $\begin{array}{l}\text { The impact on economic growth de- } \\
\text { pends on the type and amount of territo- } \\
\text { rial capital accumulated by the region. } \\
\text { The greater impact manifests in regions } \\
\text { more endowed with territorial capital. }\end{array}$ \\
\hline $\begin{array}{l}\text { Bouayad-Agha et } \\
\text { al. (2013) }\end{array}$ & 1980-2005 & $\begin{array}{l}143 \text { EU-14- } \\
\text { NUTS-1/NUTS- } \\
2 \text { regions }\end{array}$ & GMM estimator & $\begin{array}{l}\text { Economic } \\
\text { growth }\end{array}$ & $\begin{array}{l}\text { Positive impact on economic growth, } \\
\text { especially Objective } 1 \text { programmes. }\end{array}$ \\
\hline
\end{tabular}


Tab. 3. Main results of previous literature on SF effects applying quasi-experimental methodology

\begin{tabular}{|c|c|c|c|c|c|}
\hline Research by & $\begin{array}{l}\text { Covered } \\
\text { period }\end{array}$ & Units & $\begin{array}{l}\text { Econometric method } \\
\text { applied }\end{array}$ & $\begin{array}{l}\text { Outcome } \\
\text { variable }\end{array}$ & Main result \\
\hline $\begin{array}{l}\text { Garcia-Milà and } \\
\text { McGuire (2001) }\end{array}$ & $\begin{array}{l}1977-1981 \\
1989-1992\end{array}$ & $\begin{array}{l}17 \text { NUTS-2 } \\
\text { regions of Spain }\end{array}$ & $\begin{array}{l}\text { Panel: OLS and } \\
\text { difference- } \\
\text { indifference }\end{array}$ & $\begin{array}{l}\text { Economic } \\
\text { growth }\end{array}$ & $\begin{array}{l}\text { Grants are not effective in stimulating } \\
\text { private investment or improving the } \\
\text { overall economies of the poorer regions. }\end{array}$ \\
\hline $\begin{array}{l}\text { Bussoletti and } \\
\text { Esposti (2004) }\end{array}$ & $1989-2000$ & $\begin{array}{l}206 \text { NUTS-2 } \\
\text { regions of EU- } \\
15\end{array}$ & $\begin{array}{l}\text { Panel: DIFF-GMM, } \\
\text { SYS-GMM }\end{array}$ & $\begin{array}{l}\text { Economic } \\
\text { growth }\end{array}$ & $\begin{array}{l}\text { The impact of the Obj. } 1 \text { policy on growth } \\
\text { depends on the proxy used. An increase of } \\
\text { the employment share on agriculture } \\
\text { reduces the effect of SF payments. }\end{array}$ \\
\hline $\begin{array}{l}\text { Esposti and } \\
\text { Bussoletti (2008) }\end{array}$ & 1989-1999 & $\begin{array}{l}206 \text { NUTS-2 } \\
\text { regions (EU-15) }\end{array}$ & $\begin{array}{l}\text { Panel: DIFF-GMM, } \\
\text { SYS-GMM }\end{array}$ & $\begin{array}{l}\text { Economic } \\
\text { growth }\end{array}$ & $\begin{array}{l}\text { Positive impact on economic growth, but } \\
\text { it is quite limited for the whole EU. In } \\
\text { some regions or groups, it has a negligible } \\
\text { or even negative effect. }\end{array}$ \\
\hline $\begin{array}{l}\text { Becker et al. } \\
(2013)\end{array}$ & $\begin{array}{l}1989-1993 \\
1994-1999 \\
2000-2006\end{array}$ & $\begin{array}{l}186-251 \text { NUTS } \\
2 \text { regions (EU- } \\
25)\end{array}$ & $\begin{array}{l}\text { Cross sectional: a } \\
\text { fuzzy regression } \\
\text { discontinuity design } \\
\text { (RDD)+HLATE }\end{array}$ & $\begin{array}{l}\text { Economic } \\
\text { growth }\end{array}$ & $\begin{array}{l}\text { Positive impact on economic growth only } \\
\text { on about } 30 \% \text { of the regions. While the } \\
\text { treatment effect is insignificant for re- } \\
\text { gions with a very low level of absorptive } \\
\text { capacity. }\end{array}$ \\
\hline $\begin{array}{l}\text { Pellegrini et al. } \\
\text { (2013) }\end{array}$ & $\begin{array}{l}1994-1999 \\
2000-2006\end{array}$ & $\begin{array}{l}\text { NUTS-2 regions } \\
\text { (EU-15) }\end{array}$ & $\begin{array}{l}\text { Regression disconti- } \\
\text { nuity design (RDD) }\end{array}$ & $\begin{array}{l}\text { Economic } \\
\text { growth }\end{array}$ & Positive impact on economic growth. \\
\hline $\begin{array}{l}\text { Pellegrini and } \\
\text { Cerqua (2016) }\end{array}$ & $\begin{array}{l}1994-1999 \\
2000-2006 \\
2007-2013\end{array}$ & $\begin{array}{l}208 \text { NUTS-2 } \\
\text { regions (EU-15) }\end{array}$ & $\begin{array}{l}\text { Counterfactual causal } \\
\text { analysis and RDD } \\
\text { model }\end{array}$ & $\begin{array}{l}\text { Economic } \\
\text { growth }\end{array}$ & $\begin{array}{l}\text { Positive effect on economic growth. } \\
\text { However, the effect depends on the } \\
\text { intensity of transfers. }\end{array}$ \\
\hline Di Cataldo (2017) & $\begin{array}{l}1994-1999 \\
2000-2006 \\
2007-2013\end{array}$ & $\begin{array}{l}\text { Two UK NUTS- } \\
2 \text { regions: } 134 \\
\text { wards of Corn- } \\
\text { wall and the } 94 \\
\text { wards of South } \\
\text { Yorkshire }\end{array}$ & $\begin{array}{l}\text { Synthetic control } \\
\text { method, difference-in } \\
\text {-differences (DID) } \\
\text { model }\end{array}$ & $\begin{array}{l}\text { Economic } \\
\text { growth and } \\
\text { unemploy- } \\
\text { ment }\end{array}$ & $\begin{array}{l}\text { Positive impact on reduction of unem- } \\
\text { ployment and on the promotion of eco- } \\
\text { nomic growth, but this effect depends on } \\
\text { funding intensity. }\end{array}$ \\
\hline $\begin{array}{l}\text { Becker et al. } \\
(2018)\end{array}$ & $\begin{array}{l}1989-1993 \\
1994-1999 \\
2000-2006 \\
2007-2013\end{array}$ & $\begin{array}{l}\text { NUTS- } 2 \text { regions } \\
(187 \text { in } 1989-93, \\
209 \text { in } 1994-99, \\
253 \text { in } 2000-06, \\
\text { and } 253 \text { in } 2007-\end{array}$ & $\begin{array}{l}\text { A fuzzy regression } \\
\text { discontinuity design } \\
\text { (RDD) }\end{array}$ & $\begin{array}{l}\text { Economic } \\
\text { growth }\end{array}$ & $\begin{array}{l}\text { Positive impact on economic growth is } \\
\text { though not very long-lived. The effects on } \\
\text { economic growth are weaker during the } \\
\text { Crisis than before. }\end{array}$ \\
\hline
\end{tabular}

The study by Guillaumont and Chauvet (1999) was the first attempt to put forward and empirically confirms the idea that the effects of SF payments depend on specific conditioning factors. An analysis of previous contributions revealed four factors that the heterogeneity of effects can mainly depend on: 1) human capital, education (Rodríguez-Pose and Fratesi 2004, Kyriacou and Roca-Sagalés 2012 and Becker et al. 2013), 2) economic openness (Ederveen et al. 2002 and Kyriacou and Roca-Sagalés 2012), 3) regional environment (Guillaumont and Chauvet 1999, 
Cappelen et al. 2003, Becker et al. 2010 and Crescenzi and Giua 2016), and 4) institutional quality (Boldrin and Canova 2001, Ederveen et al. 2002 and 2006, Beugelsdijk and Eijffinger 2005, Kyriacou and Roca-Sagalés 2012, Becker et al. 2013, Rodríguez-Pose and Garcilazo 2015 and Arbolino and Boffardi 2017). For the summary see Tab. 4 .

Tab. 4. Main factors considered by previous studies as conditioning effects of SF payments

\begin{tabular}{|c|c|c|}
\hline Conditioning factor & The main direction of the impact & Source \\
\hline Human capital, education & $\begin{array}{l}\text { The greater positive effect of SF is observed in } \\
\text { regions with a higher level of human capital accu- } \\
\text { mulation or education. }\end{array}$ & $\begin{array}{l}\text { Rodríguez-Pose and Fratesi (2004); Kutan and } \\
\text { Yigit (2007); Becker et al. (2013); Kyriacou and } \\
\text { Roca-Sagalés (2012); Pinho et al. (2015) }\end{array}$ \\
\hline Economic openness & $\begin{array}{l}\text { The positive returns from SF transfers are higher in } \\
\text { economies that are more open. }\end{array}$ & $\begin{array}{l}\text { Ederveen et al. (2002); Kyriacou and Roca- } \\
\text { Sagalés (2012) }\end{array}$ \\
\hline $\begin{array}{l}\text { Institutional quality / } \\
\text { efficiency }\end{array}$ & $\begin{array}{l}\text { The positive returns from SF transfers are smaller in } \\
\text { regions where the institutional quality is lower } \\
\text { (corruption is higher). Regions with good institu- } \\
\text { tions distribute SF financial aids more effectively. }\end{array}$ & $\begin{array}{l}\text { Boldrin and Canova (2001); Ederveen et al. } \\
(2002,2006) \text {; Beugelsdijk and Eijffinger (2005); } \\
\text { Kutan and Yigit (2007); Bradley and Untiedt } \\
(2008) \text {; Kyriacou and Roca-Sagalés (2012); } \\
\text { Becker et al. (2013); Rodríguez-Pose and Garci- } \\
\text { lazo (2015); Tsani (2015); Dotti (2016); Arboli- } \\
\text { no and Boffardi (2017) }\end{array}$ \\
\hline
\end{tabular}

All these factors are are interlinked. Human capital, economic openness, institutional quality are the components of absorptive capacity (Khordagui and Saleh 2013). Human capital accumulation and FDI inflows depend on the institutional quality (Dias and Tebaldi 2012, Jude and Levieuge 2016, Azis 2018, etc.) and the absorptive capacity of regions (in terms of human capital) may affect FDI attraction (Noorbakhsh et al. 2001). Thus, developing a model to assess the effect of SF payments, it is conventional to include one conditioning factor, since the results could be distorted due to overlapping effects.

Kyriacou and Roca-Sagalés (2012), Arbolino and Boffardi (2017) assume that institutional quality is a key factor that can shape the effect of SF payments. According to Arbolino and Boffardi (2017), the success of the CP potentially depends on institutional quality through the regional managerial ability. Local institutions are the main stakeholders during the SF investments lifecycle, from negotiation among the European Commission (EC), national and regional governments until the distribution of funds. Thus, the quality of local institutions may lead to areas and projects where investments will be allocated. In turn, this allocation might influence the effect of SF payments. Ederveen et al. (2002) emphasize that the allocation of the SF between productive and unproductive projects, efficiency of transactions and contract enforcement depend on the bureaucratic quality of institutions and corruption. Rodríguez-Pose and Garcilazo (2015), Dellmuth et al. (2017) also emphasize the links between effectiveness of CP and regional managerial ability. Given that all conditioning factors depend on or at least are highly related to institutional quality, this factor may be considered as the main one shaping the effects of SF transfers. 
The focus of previous contributions on data on the NUTS 1 and 2 disaggregation levels is due to the fact that the majority of SF payments (except for ERDF Objective 2) are directed to solve problems arising on the NUTS 2 level. The literature review revealed that there are no studies that would examine effect of SF payments in the light of territorial disparities on the NUTS 3 level as well as studies that would analyse how institutional quality conditions the effect of SF transfers on territorial disparities. Thus, it is not clear to what extent, if any at all, SF payments focused on the NUTS 2 diminishes disparities among the smallest, i.e. the NUTS 3 administrative territories. It is an important question to answer since the decomposition of disparities across the EU shows that over the past 20 years the share attributed to the NUTS 3 level has been increasing.

\section{ESTIMATION METHOD AND DATA}

Suppose there is a CP intervention using SF transfers and we want to estimate its effect on an outcome variable, $Y$. It is assumed that this outcome depends on a set of exogenous variables, $X$, as well as on a dummy variable, $s$ such that $s_{i}=1$ if an $i$-th region has received SF payments and $s_{i}=0$ otherwise. Here we assume the homogeneous effect of SF payments. If the $i$-th region was granted for the SF over the second period $(t 2)$, we have:

$$
Y_{i, t 2}=\beta \cdot X_{i, t 2}+\delta \cdot s_{i, t 2}+e_{i, t 2}
$$

for the second (financial support or post-financial support) period,

$$
Y_{i, t 1}=\beta \cdot X_{i, t 1}+e_{i, t 1}
$$

for the first (pre-financial support) period, where $\delta$ measures the homogeneous effect of SF payment on the outcome $Y, \beta$ is the set of coefficients which define the effects of the exogenous variables $X$ on the outcome, and $e_{i}$ is the error term assumed to be uncorrelated with $X$.

Except for the truly randomized experiment, the assignment of the region for the $\mathrm{CP}$ would not be random. The non-randomness of the assignment process would likely lead to some correlation between the decision to financially support, i.e. $s_{i}$ and the error term, $e_{i}$ of the Eq. (1) based on simple cross-sectional data. This is because the decision to financially support is likely to be based on the regional characteristics that might also affect the outcome variable, $Y$, targeted by the policy. If this is true, and we are most likely unable to simultaneously control all the factors affecting the outcome variable, $Y$, as well as the decision to financially support particular regions, $s_{i}$, then we should expect a non-zero correlation between the error term, $e_{i}$, and the financial support variable, $s_{i}$. In this case, the estimator based on single cross-sectional data, which regress the outcome variable targeted by the policy on a set of regressors, would not be valid.

If pooled cross-sections over time or panel data are available, it is possible to estimate the effect of SF transfers consistently without imposing the abovementioned restrictive conditions by controlling the systematic difference, i.e. the initial gap, between the SF payment recipients and regions that are not supported. However, this method requires that the groups of regions eligible / not eligible for SF support would meet the common trend assumption. That is, if the SF transfer has not been provided, there would not exist systematic differences in the outcome variable trend of changes between the two groups over time. 
To apply diff-in-diffs estimator, we need at least two periods of data. Let $A$ and $B$ denote a group of not eligible regions and a group of SF recipients, respectively, and as previously the first period stands for pre-financial support period. The diffin-diffs estimator measures the surplus outcome growth for the regions that received SF payments compared to the financially unsupported regions, i.e. the effect of SF payments. Abstracting from other regressors except for SF payments, diff-indiffs can be estimated:

$$
\hat{\delta}_{D i D}=\left(\bar{Y}_{B, t 2}-\bar{Y}_{A, t 2}\right)-\left(\bar{Y}_{B, t 1}-\bar{Y}_{A, t 1}\right) \text {, }
$$

where $\bar{Y}_{B}$ and $\bar{Y}_{A}$ are the average outcomes for the group of regions that received $\mathrm{SF}$ payments and the group of regions that were not financially supported, respectively.

We can equivalently perform two-way ANOVA with interactions and, alternatively, diff-in-diffs that measures the homogeneous effect of SF payments can be estimated using the regression equation:

$$
Y_{i, t}=\delta_{0}+\delta_{1} \cdot t 2+\delta_{2} \cdot s_{i, t 2}+\delta_{D i D} \cdot t 2 \cdot s_{i, t 2}+\varepsilon_{i, t},
$$

where $t 2$ is a dummy variable equal to 1 for a financial support or post-financial support period and equal to 0 for a pre-financial support period. $\delta_{0}$ is equal to $\bar{Y}_{A, t 1}$. $\delta_{1}$ is equal to $\bar{Y}_{A, t 2}-\bar{Y}_{A, t 1}$ and shows how the outcome has changed without SF payments. $\delta_{2}$ is equal to $\bar{Y}_{B, t 1}-\bar{Y}_{A, t 1}$ and shows the initial gap between SF recipients and developed regions in terms of the outcome. $\delta_{D i D}$, by estimating the change in the average value of $Y$ due to SF payments shows how the initial gap $\left(\delta_{2}\right)$ between SF recipients and developed regions has changed, i.e. it is the estimated effect of SF payments.

Since we cannot expect that all regions will respond to CP in exactly the same way, simply because the amount of the SF payments is not constant across regions, we can alternatively estimate diff-in-diffs for heterogeneous effects by interacting dummy with a SF payment intensity, $S_{i}$ (SF payment to GDP ratio). If a region did not receive a SF payment, $s_{i}$ and $S_{i}$ as well as their interaction are equal to zero. If a region received SF payments, $s_{i}$ is equal to unity and its interaction with $S_{i}$ is equal to $S_{i}$. Thus $S_{i}$ substituting with $S_{i}$ we will estimate the effect of a SF payment intensity on the outcome. Eq. (3) can also be augmented by exogenous time-varying $X_{i, t}$ and constant, i.e. region-specific $Z_{i}$ variables that an outcome is assumed to depend on:

$$
Y_{i, t}=\delta_{0}^{\prime}+\delta_{1}^{\prime} \cdot t 2+\delta_{2}^{\prime} \cdot s_{i, t 2}+\delta_{D i D}^{\prime} \cdot t 2 \cdot s_{i, t 2}+\beta \cdot X_{i, t}+\gamma \cdot Z_{i}+\varepsilon_{i, t}
$$

While controlling additional factors and/or $s_{i}$ substituting with $S_{i}, \hat{\delta}{ }^{\prime}{ }_{D i D}$ cannot be written as in Eq. (2), that is why we separate parameters by introducing primes in their marking. Nevertheless, we interpret it in the same way $-\delta_{D I D}^{\prime}$ by measuring the effect of a SF payment intensity change by one unit on the outcome which estimates the effect of SF payment. $\delta_{2}^{\prime}$ shows the correlation between the SF payment intensity over a support period and the outcome variable level over aprefinancial support period.

If we apply time-demeaned transformation or fixed effects (FE) estimator, it would allow us to control all region-specific time-constant factors, $Z_{i}$, because after 
the aforementioned transformations any time-constant factors (observed or unobserved) would equal zero.

As the literature review revealed, institutional quality among others is considered as a factor conditioning the effect of SF payments. Put in other words, the $S_{i}$ effect on $Y$, i.e. $\delta_{D i D}^{\prime}$ in Eq. (4) is not homogeneous across all $i$, but hinges on factors that vary across $i$. Within the framework of our model, we will analyze a situation where the factor potentially conditioning effect of SF payments is intervalratio variable. The equation of our interest is:

$$
\begin{aligned}
& Y_{i, t}=\delta_{0}^{\prime \prime}+\delta_{1}^{\prime \prime} \cdot t 2+\delta_{2}^{\prime \prime} \cdot S_{i, t 2}+\delta_{3}^{\prime \prime} \times E Q I_{i, t 2}+\delta_{23}^{\prime \prime} \cdot S_{i, t 2} \times E Q I_{i, t 2}+\delta_{D i D 2}^{\prime \prime} \cdot t 2 \\
& \times E Q I_{i, t 2}+\delta_{D i D 12}^{\prime \prime} \cdot t 2 \cdot S_{i, t 2} \times E Q I_{i, t 2}+\beta \cdot X_{i, t}+\gamma \cdot Z_{i}+\varepsilon_{i, t},
\end{aligned}
$$

where EQI is the European Quality of Government Index used to proxy institutional quality at a regional level.

The interactive equation, as Eq. (5) shows conditional effects. Since $S$ and EQI are interval-ratio variables, Eq. (5) after a time-demeaned transformation ("stands for time-demeaned variable) for the second $(t 2=1)$ period can be factored and rearranged in a way to yield two equations. One that estimates the conditional relationship between $Y$ and $S$ for specified values of $E Q I$,

$$
\begin{aligned}
& \ddot{Y}_{i, t 2}=\left(\delta_{0}^{\prime \prime}+\delta_{1}^{\prime \prime}+\delta_{D i D 2}^{\prime \prime} \times \ddot{E} Q I_{i, t 2}\right)+\left(\delta_{D i D 1}^{\prime \prime}+\delta_{D i D 12}^{\prime \prime} \cdot \ddot{E} Q I_{i, t 2}\right) \\
& \ddot{S}_{i, t 2}+\beta \cdot X_{i, t 2}+\varepsilon_{i},
\end{aligned}
$$

in which both the intercept and slope of $Y$ on $S$ vary according to the value of $E Q I$. The other equation estimates the conditional relationship between $Y$ and $E Q I$ for specified values of $S$,

$$
\begin{aligned}
& \ddot{Y}_{i, t 2}=\left(\delta_{0}^{\prime \prime}+\delta_{1}^{\prime \prime}+\delta_{D i D 1}^{\prime \prime} \cdot \ddot{S}_{i, t 2}\right)+\left(\delta_{D i D 2}^{\prime \prime}+\delta_{D i D 12}^{\prime \prime} \cdot \ddot{S}_{i, t 2}\right) \\
& \times \ddot{E} Q I_{i, t 2}+\beta \cdot \ddot{X}_{i, t}+\varepsilon_{i},
\end{aligned}
$$

in which both the intercept and the slope of $Y$ on $E Q I$ vary according to the value of $S$. In our case, just Eq. (5a) is of main interest. Viewing the Eq. (5a) in conditional terms, the coefficient stands as a baseline slope against which the changes in slope can be measured. The baseline is set at the point where for $Y$ on $S, E Q I$ equals to zero. Thus $\delta^{\prime \prime}{ }_{D i D 1}$ could be interpreted as the effect of SF payments, when $E Q I$ equals zero.

Following Friedrich (1982), we can argue, that not just the effect of $S$ on $Y$ is conditioned on the value of the EQI, as Eq. (5a) shows, but also the standard error of the slope coefficient is also conditioned on the EQI value and the standard error of the sum $\left(\delta^{\prime \prime}{ }_{D i D 1}+\delta^{\prime \prime}{ }_{D i D 12} \cdot E Q I_{i, t 2}\right)$ is:

$$
\begin{aligned}
& S E_{\left(\delta_{D D 1}^{\prime \prime}+\delta_{D i D 12}^{\prime \prime} \cdot E Q I_{i, t 2}\right)}=\sqrt{\operatorname{var}\left(\delta_{D i D 1}^{\prime \prime}\right)+E Q I_{i, t 2}^{2} \cdot \operatorname{var}\left(\delta_{D i D 12}^{\prime \prime}\right)} \\
& +2 \cdot E Q I_{i, t 2} \cdot \operatorname{cov}\left(\delta_{D i D 1}^{\prime \prime}, \delta_{D i D 12}^{\prime \prime}\right)
\end{aligned}
$$

Since the standard error is not constant and is non-linearly related with $E Q I$, this also implies that there could be values of $E Q I$ over which the estimated effect of SF payments is not significant, i.e. there is no statistically significant effect of $S$ on $Y$. In line with the usual logic of constructing for a coefficient a test of statistical 
significance against the possibility that the population parameter is zero, the $t$ value for the $S$ effect on $Y$ can be calculated, when $E Q I$ is added to the equation, as:

$$
t=\frac{\delta_{D i D 1}^{\prime \prime}+\delta_{D i D 12}^{\prime \prime} \cdot E Q I_{i, t 2}}{S_{\left(\delta_{D i D 1}^{\prime \prime}+\delta_{D i D 12}^{\prime \prime} \cdot E Q I_{i, t 2}\right)}} .
$$

The data used for the empirical analysis is on the NUTS 3 level covering in total (including a robustness check) a period of $1995-2014$. Since we aim to assess the effect of SF payments over 2000-2006 PP we include all EU regions except Romania, Bulgaria and Croatia, i.e. countries that joined the EU after the PP under consideration ended. For 2000-2006 the SWECO (2008) database contains data for the Cohesion Fund (CF), European Regional Development Fund (ERDF) Objective 1, ERDF Objective 2, URBAN and INTERREG IIIA allocations. The total amount mapped in the database for NUTS 3 is 149.819 bill. EUR which is $93.5 \%$ of the total CF and ERDF budget for 2000 - 2006. Over this PP, 1007 NUTS 3 regions received SF payments and 254 developed regions did not. The SF payments intensity (dedicated ERDF and CF funds combined over a financial support period to GDP over the same period ratio, \%), i. e. $S_{i, t 2}$ ranges from 0.0002 up to 13.5060 with an average and median value of 0.5043 and 0.1427 , respectively.

As the outcome variable, $Y_{i, t}$, to estimate the effect of SF payments on regional disparities in terms of their development level, we use data on a regional per capita GDP at constant (2010) prices collected from Eurostat. The correlation between $S_{i, t 2}$ and $Y_{i, t 1}$ is $-0.4028(\mathrm{n}=1007)$. Being statistically significant ( $\mathrm{p}$-value $\left.<0.0001\right)$ the negative correlation suggests that the intensity of SF payments was higher in regions that we re less developed over 1995 - 1999, i.e. the period considered in our research as a pre-financial support period. $2007-2011$ we consider as a postfinancial support period. We use a period average of the outcome variable to reduce the impact of fluctuations due to business cycles and considering that it takes time for the effect to manifest and because data on SF payments are provided for the entire PP rather than on yearly bases. To account for the non-common trend of growth, we inflated per capita GDP by the rate equal to the difference in growth rates between SF beneficiaries and not supported regions. dta $Y_{i, t}$ stands for differential-trend-adjusted per capita GDP. Period averages of regional per capita GDP for the SF recipients and unsupported regions are presented in Tab. 5.

Since the earliest data on EQI provided by the Quality of Government Institute are available for 2010 (Charron et al. 2010), following Rodríguez-Pose and Garcilazo (2015) and Charron et al. (2014), we interpolated values for the year 2003 (midyear of $2000-2006$ PP). We have done that by combining the data on EQI for the NUTS 2 regions with the World Bank's World Governance Indicators, available at the national institutional quality across regions of the EU. The assumptions for interpolation are that 1 ) regional variations of institutional quality on the NUTS 2 level within countries are relatively stable and 2) variations at a national level are captured by the World Bank's World Governance Indicators. Details on how this indicator is calculated can be found in Charron et al. (2014).

The estimated data for $E Q I$ over 2003, i.e. $E Q I_{i, t 2}$ range from -2.2845 to 1.7620 and an estimated correlation coefficient with $Y_{i, t 2}$ is 0.3572 (p-value $<0.0001$, 
$\left.\mathrm{n}=1247^{1}\right)$. This correlation in the group of SF beneficiaries is 0.4392 ( $\mathrm{p}$-value $<0.0001, \mathrm{n}=1004$ ), in the group of unsupported regions is 0.2520 (p-value $=0.0001, \mathrm{n}=243$ ). The correlation between $S_{i, t 2}$ and $E Q I_{i, t 2}$ is -0.3871 (p-value $<0.0001, \mathrm{n}=1004)$ and shows that less developed regions with a lower institutional quality received more intense SF payments.

Tab. 5. Period averages of regional per capita GDP at constant prices

\begin{tabular}{|c|c|c|c|c|c|c|c|c|c|}
\hline (1) & (2) & (3) & (4) & (5) & (6) & (7) & (8) & (9) & (10) \\
\hline Outcome, $Y$ & & & $\begin{array}{l}\text { Pre-financial } \\
\text { support } \\
\text { period }\end{array}$ & $\begin{array}{l}\text { Financial } \\
\text { support } \\
\text { period } \\
2000-2006)\end{array}$ & $\begin{array}{c}\text { Post-financial } \\
\text { support period } \\
(2007-2011)\end{array}$ & (5)-(4) & (6)-(4) & $\begin{array}{c}(5)-(4), \\
\%\end{array}$ & $\begin{array}{c}(6)-(4), \\
\%\end{array}$ \\
\hline \multirow{4}{*}{$\begin{array}{l}\text { Period average } \\
\text { regional per } \\
\text { capita GDP at } \\
\text { constant prices } \\
(Y)\end{array}$} & (a) & $\begin{array}{l}\text { Regions that } \\
\text { did not re- } \\
\text { ceived SF } \\
\text { payments }\end{array}$ & 26034.5 & 30616.2 & 32873.6 & 4581.7 & 6839.1 & 17.6 & 26.3 \\
\hline & (b) & $\begin{array}{l}\text { Regions that } \\
\text { received SF } \\
\text { payments }\end{array}$ & 19829.2 & 23012 & 24435.2 & 3182.8 & 4606 & 16.1 & 23.2 \\
\hline & (c) & (b)-(a) & -6205.3 & -7604.2 & -8438.4 & $-1398.9^{(2)}$ & $-2233.1^{(2)}$ & & \\
\hline & (d) & (b)-(a), $\%$ & -23.8 & -24.8 & -25.7 & & & 4.2 & 7.4 \\
\hline \multirow{4}{*}{$\begin{array}{l}\text { Period average } \\
\text { differential- } \\
\text { trend-adjusted } \\
\text { regional per } \\
\text { capita GDP at } \\
\text { constant prices } \\
\quad(\text { dta } Y)^{(1)}\end{array}$} & (e) & $\begin{array}{l}\text { Regions that } \\
\text { did not re- } \\
\text { ceived SF } \\
\text { payments }\end{array}$ & 26173.5 & 31263.1 & 34090.7 & 5089.6 & 7917.2 & 19.4 & 30.2 \\
\hline & (f) & $\begin{array}{l}\text { Regions that } \\
\text { received SF } \\
\text { payments }\end{array}$ & 19829.2 & 23012 & 24435.2 & 3182.8 & 4606 & 16.1 & 23.2 \\
\hline & (g) & (f)-(e) & -6344.3 & -8251.1 & -9655.5 & $-1906.8^{(2)}$ & $-3311.2^{(2)}$ & & \\
\hline & (h) & (f)-(e), $\%$ & -24.2 & -26.4 & -28.3 & & & 8.9 & 15.5 \\
\hline
\end{tabular}

Notes: (1) Average growth rate of regional per capita GDP at constant prices over $1995-1999$ was $2.36 \%$ and $2.62 \%$ for more developed and SF recipients groups, respectively. The difference in growth trends was used for the adjustment. (2) Calculated (based on Eq. 2) diff-in-diffs, i.e. $\hat{\delta}$ DiD.

\section{ESTIMATIONS AND ROBUSTNESS CHECK}

Table 6 reports estimates of Eq. (5). The estimated conditional slopes (effects) over the observed range of EQI based on estimates in Tab. 6 without control variables are presented in Fig.1a. We see that effect is positive over all the observed range of $E Q I$ values for estimations over the financial support period. Over the post -financial support period, for some extremely low values of $E Q I$ the effect is negative. There is not much difference in conditional slopes based on simple and differential-trend-adjusted per capita GDP. On the other hand, the relation between the

\footnotetext{
${ }^{1}$ Data on EQI is not available for 3 NUTS 3 regions - Ciudad Autónoma de Ceuta and Ciudad Autónoma de Melilla in Spain, and for Mayotte in France.
} 
effect of the SF payment and EQI differs for financial support and post-financial support periods. For the financial support period, we see that higher values of $E Q I$ correspond to lower values of the SF payments' effect, i.e. the slope is negative. Despite the fact that slopes are quite small, it implies that in the short-run a higher effect on reducing interregional disparities would have a policy intended to direct more SF payments to the regions with a low EQI. Because EQI and per capita GDP are positively correlated, it seems that more SF payments for the regions with the lowest per capita GDP would allow the reduction of the gap of development level among regions in the shortest period of time. It does not necessarily mean that this effect would be long-lasting, since over the financial support period we can observe the dummy effect of SF payments which occurs just due to the fact that transfers will increase regional per capita GDP as an additional expenditure in the economy.

Tab. 6. Fixed effects estimates of Eq. (5)

\begin{tabular}{|c|c|c|c|c|c|}
\hline \multirow{2}{*}{ Variable } & \multirow{2}{*}{ Parameter } & \multicolumn{2}{|c|}{ Financial support period } & \multicolumn{2}{|c|}{$\begin{array}{l}\text { Post-financial support } \\
\text { period }\end{array}$} \\
\hline & & $\operatorname{Ln}(Y)$ & $\operatorname{Ln}(\mathrm{dtaY})$ & $\operatorname{Ln}(Y)$ & $\operatorname{Ln}(\mathrm{dtaY})$ \\
\hline \multirow{2}{*}{ Intercept } & \multirow{2}{*}{$\delta^{\prime \prime}{ }_{0}$} & $9.8190 * * *$ & $9.8200^{* * *}$ & $9.8190 * * *$ & $9.8200 * * *$ \\
\hline & & $(0.0017)$ & $(0.0017)$ & $(0.0023)$ & $(0.0023)$ \\
\hline \multirow{2}{*}{$t 2$} & \multirow{2}{*}{$\delta^{\prime \prime}{ }_{1}$} & $0.1590 * * *$ & $0.1624 * * *$ & $0.2289 * * *$ & $0.2357 * * *$ \\
\hline & & $(0.0042)$ & $(0.0042)$ & $(0.0069)$ & $(0.0070)$ \\
\hline \multirow{2}{*}{$t 2 \cdot S_{i, t 2}$} & \multirow{2}{*}{$\delta_{D i D 1}^{\prime \prime}$} & $0.0061 * *$ & 0.0044 & $0.0222 * * *$ & $0.0188 * * *$ \\
\hline & & $(0.0029)$ & $(0.0030)$ & $(0.0048)$ & $(0.0044)$ \\
\hline \multirow{2}{*}{$t 2 \times E Q I_{i, t 2}$} & \multirow{2}{*}{$\delta^{\prime \prime}{ }_{D i D 2}$} & $-0.0151 * * *$ & $-0.0145^{* * *}$ & $-0.0254 * * *$ & $-0.0242 * * *$ \\
\hline & & $(0.0054)$ & $(0.0054)$ & $(0.0086)$ & $(0.0088)$ \\
\hline \multirow{2}{*}{$t 2 \cdot S_{i, t 2} \times E Q I_{i, t 2}$} & \multirow{2}{*}{$\delta_{D i D 12}^{\prime \prime}$} & -0.0011 & -0.0018 & 0.0102 & 0.0087 \\
\hline & & $(0.0079)$ & $(0.0079)$ & $(0.0090)$ & $(0.0089)$ \\
\hline$X_{i, t}$ & $\beta$ & Not est. & Not est. & Not est. & Not est. \\
\hline \multicolumn{6}{|c|}{ Variance-covariance } \\
\hline \multicolumn{2}{|c|}{$\operatorname{var}\left(\delta_{D i D 1}^{\prime \prime}\right)$} & $8.25 \mathrm{E}-06$ & $9.24 \mathrm{E}-06$ & $2.29 \mathrm{E}-05$ & $1.95 \mathrm{E}-05$ \\
\hline \multicolumn{2}{|c|}{$\operatorname{var}\left(\delta^{\prime \prime}{ }_{D i D 12}\right)$} & $6.18 \mathrm{E}-05$ & $6.25 \mathrm{E}-05$ & $8.07 \mathrm{E}-05$ & $7.87 \mathrm{E}-05$ \\
\hline \multicolumn{2}{|c|}{$\operatorname{cov}\left(\delta^{\prime \prime}{ }_{D i D 1}, \delta^{\prime \prime}{ }_{D i D 12}\right)$} & $-1.59 \mathrm{E}-06$ & $-9.08 \mathrm{E}-07$ & $2.16 \mathrm{E}-06$ & $-8.90 \mathrm{E}-07$ \\
\hline \multicolumn{2}{|c|}{ Sample size } & 2494 & 2494 & 2494 & 2494 \\
\hline \multicolumn{2}{|c|}{ Within R-squared } & 0.4713 & 0.4731 & 0.5233 & 0.5264 \\
\hline
\end{tabular}

Notes: Robust (using HCCME) standard errors presented in parentheses. *, **, *** indicate statistical significance at the $10 \%, 5 \%$, and $1 \%$ levels, respectively. 
a)

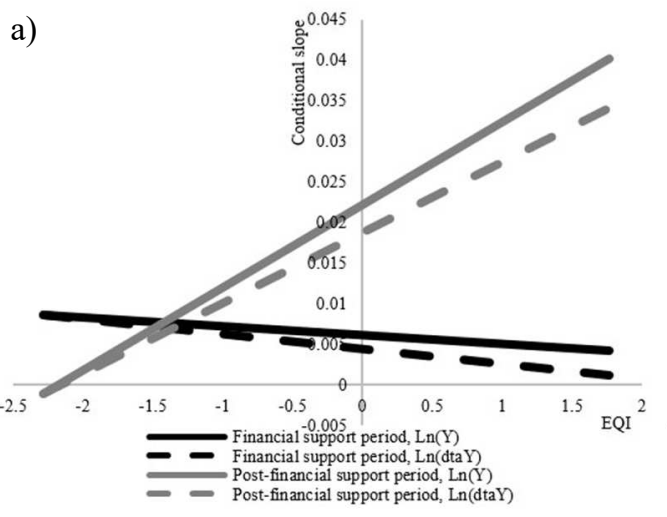

c)

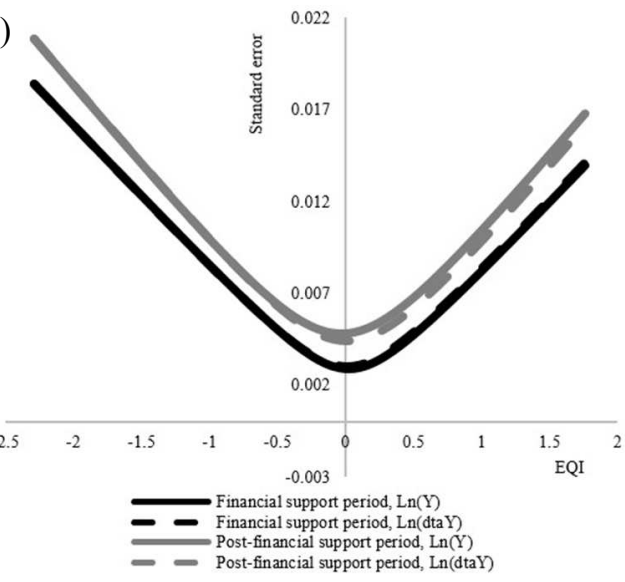

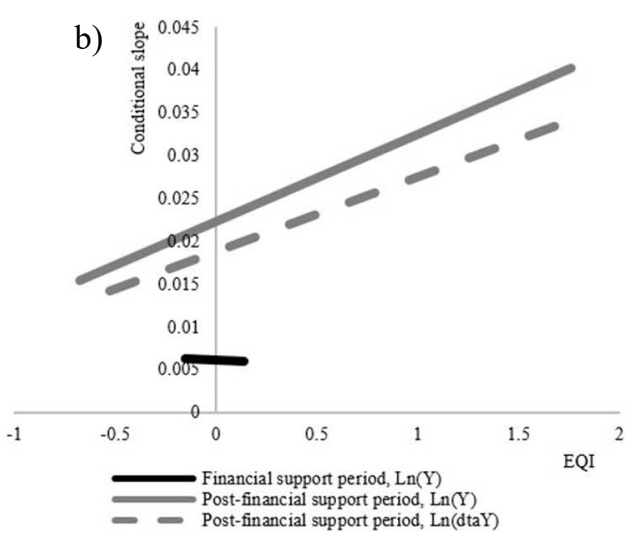

d)

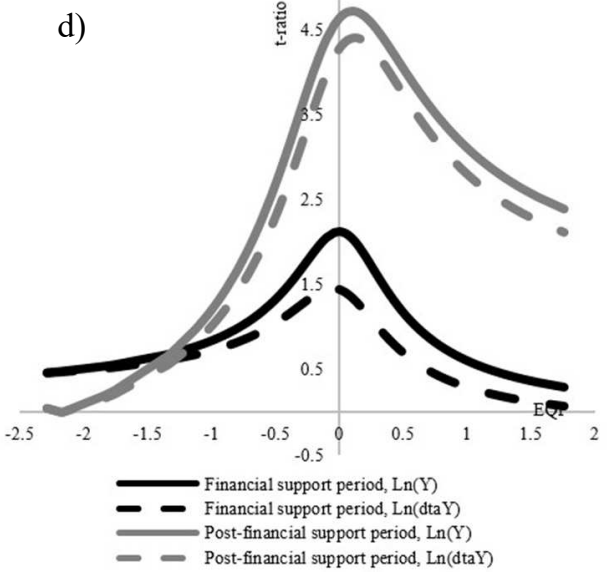

Fig. 1. a) Conditional slope over all observed ranges of $E Q I$ values. b) Conditional slope over the range of $E Q I$ values, for which it is statistically significant. c) Standard errors of the estimated conditional slope. d) $t$-ratios of the estimated conditional slope

On the contrary, the relation between the effect of SF payments and EQI over the post-financial support period is positive. This could imply that we can expect disparities to shrink more between regions in the long-run if we applied a policy that would direct more SF payments to the regions with a higher $E Q I$ (what would not necessarily diminish disparities in the short-run if we consider projects having long-lasting but not instantly visible effects). Since a higher EQI corresponds to higher institutional quality, our findings imply that good institutions in the regions that receive SF payments is a crucial factor for the effect of this support to be longlasting.

Another question of interest is whether estimated conditional effects are statistically significant over the all observed range of EQI. Using variance-covariance in Tab. 6, Eq. (6) and (7) we calculated standard errors (see Fig. 1c) and $t$-ratios (see Fig. 1d) of conditional slopes for the observed range of EQI. Based on the $t$-ratios reported in Fig. 1d, Fig. 1b displays the effects of SF payments conditioned on the 
values of $E Q I$ for which estimated effect was statistically significant.

We see that for the financial support period, the estimated effect of SF payments is statistically significant just over a very narrow range of $E Q I$ values (from -0.1530 up to 0.1370 ) and just if we consider a simple per capita GDP. In this range, there were just 63 regions out of 1004 financially supported for which the EQI was possible to estimate.

Over the post-financial support period, the range of $E Q I$ for which the estimated effect of SF payments was statistically significant is much wider - from -0.6750 and -0.5270 for the estimations with simple and differential-trend-adjusted per capita GDP, respectively, up to the highest observed value of $E Q I-1.7620$. For these EQI values, we observe 819 regions that account for $81.6 \%$ and 798 regions that account for $79.5 \%$ of financially supported regions, respectively.

Figure 2 reports estimated conditional slope, standard error and $t$-ratio based on fixed effects estimates of the same Eq. (5) but with time-varying factors $\mathrm{X}_{i, t}$, presented in Tab. 7. Estimations also show that EQI positively and statistically significantly correlates with the effect of SF payments just over the post-financial support period.

Tab. 7. Fixed effects estimates of Eq. (5) with control variables

\begin{tabular}{|c|c|c|c|c|c|}
\hline \multirow{2}{*}{ Variable } & \multirow{2}{*}{ Parameter } & \multicolumn{2}{|c|}{ Financial support period } & \multicolumn{2}{|c|}{$\begin{array}{l}\text { Post-financial support } \\
\text { period }\end{array}$} \\
\hline & & $\operatorname{Ln}(\mathrm{Y})$ & $\operatorname{Ln}(\mathrm{dtaY})$ & $\operatorname{Ln}(\mathrm{Y})$ & $\operatorname{Ln}(\mathrm{dtaY})$ \\
\hline \multirow{2}{*}{ Intercept } & \multirow{2}{*}{$\delta^{\prime \prime}{ }_{0}$} & $9.8670 * * *$ & $9.8650 * * *$ & $9.7651^{* * *}$ & $9.7619 * * *$ \\
\hline & & $(0.0345)$ & $(0.0347)$ & $(0.0405)$ & $(0.0406)$ \\
\hline \multirow{2}{*}{$t 2$} & \multirow{2}{*}{$\delta^{\prime \prime}{ }_{1}$} & $0.1372 * * *$ & $0.1410^{* * *}$ & $0.2120 * * *$ & $0.2199 * * *$ \\
\hline & & $(0.0058)$ & $(0.0059)$ & $(0.0088)$ & $(0.0088)$ \\
\hline \multirow{2}{*}{$t 2 \cdot S_{i, t 2}$} & \multirow{2}{*}{$\delta_{D i D 1}^{\prime \prime}$} & 0.0026 & 0.0010 & 0.0100 & 0.0069 \\
\hline & & $(0.0043)$ & $(0.0044)$ & $(0.0065)$ & $(0.0067)$ \\
\hline \multirow{2}{*}{$t 2 \times E Q I_{i, t 2}$} & \multirow{2}{*}{$\delta^{\prime \prime}{ }_{D i D 2}$} & -0.0016 & -0.0011 & -0.0098 & -0.0090 \\
\hline & & $(0.0059)$ & $(0.0059)$ & $(0.0087)$ & $(0.0088)$ \\
\hline \multirow{2}{*}{$t 2 \cdot S_{i, t 2} \times E Q I_{i, t 2}$} & \multirow{2}{*}{$\delta^{\prime \prime}{ }_{D i D 12}$} & 0.0031 & 0.0024 & 0.0128 & 0.0112 \\
\hline & & $(0.0074)$ & $(0.0074)$ & $(0.0093)$ & $(0.0093)$ \\
\hline$X_{i, t}$ & $\beta$ & Est. & Est. & Est. & Est. \\
\hline \multicolumn{6}{|c|}{ Variance-covariance } \\
\hline \multicolumn{2}{|c|}{$\operatorname{var}\left(\delta_{D i D 1}^{\prime \prime}\right)$} & $1.82 \mathrm{E}-05$ & $1.96 \mathrm{E}-05$ & $4.17 \mathrm{E}-05$ & $4.55 \mathrm{E}-05$ \\
\hline \multicolumn{2}{|c|}{$\operatorname{var}\left(\delta^{\prime \prime}{ }_{D i D 12}\right)$} & $5.45 \mathrm{E}-05$ & $5.47 \mathrm{E}-05$ & $8.59 \mathrm{E}-05$ & $8.59 \mathrm{E}-05$ \\
\hline \multicolumn{2}{|c|}{$\operatorname{cov}\left(\delta^{\prime \prime}{ }_{D i D 1}, \delta^{\prime \prime}{ }_{D i D 12}\right)$} & $3.84 \mathrm{E}-06$ & $3.74 \mathrm{E}-06$ & $2.3 \mathrm{E}-06$ & $1.56 \mathrm{E}-06$ \\
\hline \multicolumn{2}{|c|}{ Sample size } & 2498 & 2498 & 2498 & 2498 \\
\hline \multicolumn{2}{|c|}{ Within R-squared } & 0.6289 & 0.6355 & 0.6723 & 0.6797 \\
\hline
\end{tabular}

Notes: Robust (using HCCME) standard errors presented in parentheses. *, **, *** indicate statistical significance at the $10 \%, 5 \%$, and $1 \%$ levels, respectively. 
The robustness of our fixed effects estimates is ensured, first of all, by slightly changing the specification of the equations, i.e. estimating them with and without time-varying factors. Estimated diff-in-diffs parameters with $X_{i, t}$ presented in Tab. 7 are consistent with estimated parameters without $X_{i, t}$ presented in the Tab. 6 .

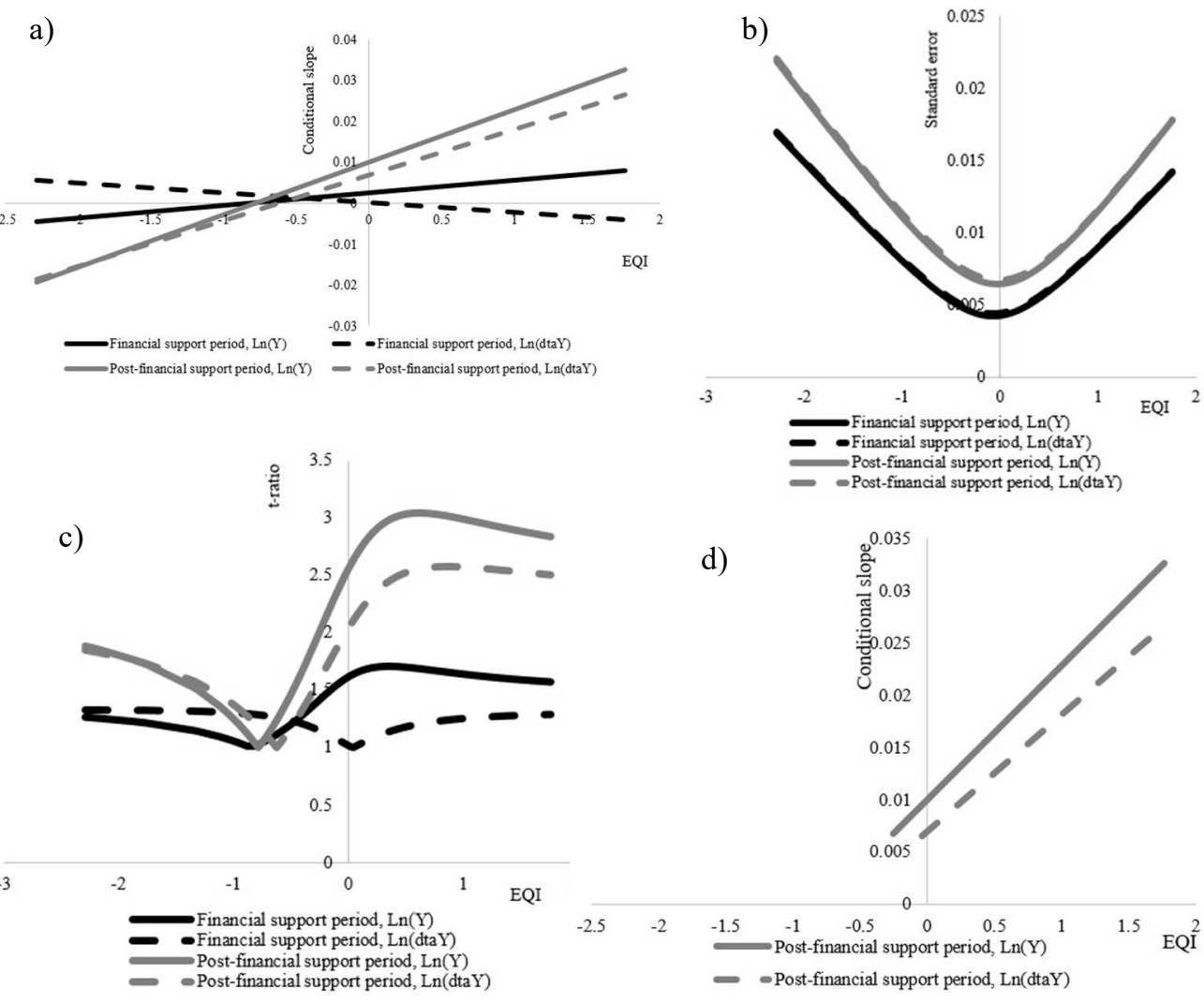

Fig. 2. a) Conditional slope over all observed ranges of $E Q I$ values, b) Standard errors of the estimated conditional slope, c) $t$-ratios of the estimated conditional slope, d) Conditional slope over the range of $E Q I$ values, for which it is statistically significant

Another attempt to check the robustness of the general estimates is related to changing the post-financial support period. In our general estimations, we considered $2007-2011$ as a post-policy period. We re-estimated our equation for the alternative $2010-2014$ post-policy period. Since the $n+2$ and $n+3$ rules for the 2000 -2006 PP allowed the EU MS to spend the last allocation available until the end of 2008 and for Central and Eastern EU Member States until the end of 2009, some of the positive effects could be omitted analysing the 2007 - 2011 period since the absorption capacity increased progressively when the end of the PP approached. Shifting forward the post-policy period allows us as well to minimise the effect of the financial crisis, which is covered by the post-policy period in the general estimations. This shift is not without consequences since there is a possibility to capture the effects of the next, i.e. 2007 - 2013 PP. General (over 2007 - 2011) and re- 
estimated (over 2010 - 2014) diff-in-diffs parameters for the whole sample size are compared in Tab. 8. Estimated diff-in-diffs parameters over 2010 - 2014 appeared as consistent with general ones in terms of statistical significance. As for the size of the parameters, for the alternative post-financial period, they appeared slightly bigger which can be explained by omitting the impact of the financial crisis or the more lagging positive effects of SF and also by capturing the effects of financing over the next PP.

Tab. 8. Fixed effects estimates of a diff-in-diffs parameter over the alternative postfinancial support period

\begin{tabular}{|c|c|c|c|c|}
\hline & \multicolumn{2}{|c|}{$\begin{array}{l}\text { General post-financial support } \\
\text { period }(2007-2011)\end{array}$} & \multicolumn{2}{|c|}{$\begin{array}{l}\text { Alternative post-financial support } \\
\text { period }(2010-2014)\end{array}$} \\
\hline & $\operatorname{Ln}(\mathrm{Y})$ & $\operatorname{Ln}(\mathrm{dtaY})$ & $\operatorname{Ln}(Y)$ & $\operatorname{Ln}(\mathrm{dtaY})$ \\
\hline \multirow{2}{*}{$\delta^{\prime \prime}{ }_{D i D 1}$} & $0.0222 * * *$ & $0.0188^{* * *}$ & $0.0248 * * *$ & $0.0208 * * *$ \\
\hline & $(0.0048)$ & $(0.0044)$ & $(0.0057)$ & $(0.0047)$ \\
\hline \multirow{2}{*}{$\delta_{D i D 2}^{\prime \prime}$} & $-0.0254 * * *$ & $-0.0242 * * *$ & $-0.0280 * * *$ & $-0.0273 * * *$ \\
\hline & $(0.0086)$ & $(0.0087)$ & $(0.0100)$ & $(0.0103)$ \\
\hline \multirow{2}{*}{$\delta^{\prime \prime}{ }_{D i D 12}$} & 0,0102 & 0,0087 & 0,0109 & 0,01 \\
\hline & $(0.0090)$ & $(0.0089)$ & $(0.0103)$ & $(0.0101)$ \\
\hline$\beta$ & Not est. & Not est. & Not est. & Not est. \\
\hline \multirow{2}{*}{$\delta_{D i D 1}^{\prime \prime}$} & 0,01 & 0,0069 & 0,0106 & 0,0074 \\
\hline & $(0.0065)$ & $(0.0067)$ & $(0.0070)$ & $(0.0079)$ \\
\hline \multirow{2}{*}{$\delta^{\prime \prime}{ }_{D i D 2}$} & $-0,0098$ & $-0,009$ & $-0,0106$ & $-0,0095$ \\
\hline & $(0.0087)$ & $(0.0088)$ & $(0.0094)$ & $(0.0094)$ \\
\hline \multirow{2}{*}{$\delta^{\prime \prime}{ }_{D i D 12}$} & 0,0128 & 0,0112 & 0,0148 & 0,0126 \\
\hline & $(0.0093)$ & $(0.0093)$ & $(0.0100)$ & $(0.0103)$ \\
\hline$\beta$ & Est. & Est. & Est. & Est. \\
\hline
\end{tabular}

Notes: Robust (using HCCME) standard errors presented in parentheses. *, **, *** indicate statistical significance at the $10 \%, 5 \%$, and $1 \%$ levels, respectively.

Tab. 9. Fixed effects estimates of the diff-in-diffs parameter for the reduced sample

\begin{tabular}{|c|c|c|c|c|c|c|c|c|}
\hline \multirow{3}{*}{ Parameter } & \multicolumn{4}{|c|}{ Fixed effects estimates for the full sample } & \multicolumn{4}{|c|}{ Fixed effects estimates for reduced sample } \\
\hline & \multicolumn{2}{|c|}{ Financial support period } & \multicolumn{2}{|c|}{ Post-financial support period } & \multicolumn{2}{|c|}{ Financial support period } & \multicolumn{2}{|c|}{ Post-financial support period } \\
\hline & $\operatorname{Ln}(Y)$ & $\operatorname{Ln}(\mathrm{dtaY})$ & $\operatorname{Ln}(Y)$ & $\operatorname{Ln}(\mathrm{dta} Y)$ & $\operatorname{Ln}(\mathrm{Y})$ & $\operatorname{Ln}(\mathrm{dtaY})$ & $\operatorname{Ln}(Y)$ & $\operatorname{Ln}(\mathrm{dtaY})$ \\
\hline \multirow{2}{*}{$\delta_{D i D 1}^{\prime \prime}$} & $0.0061 * *$ & 0,0044 & $0.0222 * * *$ & $0.0188 * * *$ & $0.0063 * *$ & 0,0042 & $0.0254 * * *$ & $0.0201 * * *$ \\
\hline & $(0.0029)$ & $(0.0030)$ & $(0.0048)$ & $(0.0044)$ & $(0.0030)$ & $(0.0030)$ & $(0.0054)$ & $(0.0053)$ \\
\hline \multirow{2}{*}{$\delta_{D i D 1}^{\prime \prime}$} & $-0.0151 * * *$ & $-0.0145 * * *$ & $-0.0254 * * *$ & $-0.0242 * * *$ & $-0.0157 * * *$ & $-0.0143^{* * *}$ & $-0.0298 * * *$ & $-0.0263 * * *$ \\
\hline & $(0.0054)$ & $(0.0054)$ & $(0.0086)$ & $(0.0087)$ & $(0.0054)$ & $(0.0058)$ & $(0.0102)$ & $(0.0108)$ \\
\hline \multirow{2}{*}{$\delta_{D i D 1}^{\prime \prime}$} & $-0,0011$ & $-0,0018$ & 0,0102 & 0,0087 & $-0,001$ & $-0,0018$ & 0,0109 & 0,0091 \\
\hline & $(0.0079)$ & $(0.0079)$ & $(0.0090)$ & $(0.0089)$ & $(0.0080)$ & $(0.0073)$ & $(0.0103)$ & $(0.0094)$ \\
\hline$\beta$ & Not est. & Not est. & Not est. & Not est. & Not est. & Not est. & Not est. & Not est. \\
\hline \multirow{2}{*}{$\delta_{D i D 1}^{\prime \prime}$} & 0,0026 & 0,001 & 0,01 & 0,0069 & 0,0028 & 0,001 & 0,0117 & 0,0074 \\
\hline & $(0.0043)$ & $(0.0044)$ & $(0.0065)$ & $(0.0067)$ & $(0.0044)$ & $(0.0041)$ & $(0.0078)$ & $(0.0067)$ \\
\hline \multirow{2}{*}{$\delta_{D i D 1}^{\prime \prime}$} & $-0,0016$ & $-0,0011$ & $-0,0098$ & $-0,009$ & $-0,0014$ & $-0,001$ & $-0,0094$ & $-0,0088$ \\
\hline & $(0.0059)$ & $(0.0059)$ & $(0.0087)$ & $(0.0088)$ & $(0.0063)$ & $(0.0054)$ & $(0.0099)$ & $(0.0086)$ \\
\hline \multirow{2}{*}{$\delta_{D i D 1}^{\prime \prime}$} & 0,0031 & 0,0024 & 0,0128 & 0,0112 & 0,0029 & 0,0026 & 0,0136 & 0,0141 \\
\hline & $(0.0074)$ & $(0.0074)$ & $(0.0093)$ & $(0.0093)$ & $(0.0070)$ & $(0.0071)$ & $(0.0098)$ & $(0.0096)$ \\
\hline$\beta$ & Est. & Est. & Est. & Est. & Est. & Est. & Est. & Est. \\
\hline
\end{tabular}

Notes: Robust (using HCCME) standard errors presented in parentheses. *, **, *** indicate statistical significance at the $10 \%, 5 \%$, and $1 \%$ levels, respectively. 
The next attempt to check the robustness of the general estimates is related to omitting from the sample SF beneficiaries with relatively extreme $S_{i, t 2}$ values, i.e. below the bottom 5 th percentile $(0.005)$ and above the 95 th percentile $(2.11)$. That reduced number of SF recipients from 1007 regions down to 908 but the range of observed $E Q I$ values did not change. General (for the full sample) and re-estimated (for the reduced sample) diff-in-diffs parameters for the general financial support and post-financial support periods are presented in Tab. 9. Estimated diff-in-diffs parameters for the reduced sample appeared consistent with general ones in terms of statistical significance, size and direction.

The last robustness check related to changing the strategy applied to examine how institutional quality potentially conditions the effect of SF payments. We construct a dummy variable, $d h$, such that $d h_{i, t 2}=1$ if region $i$ has an $E Q I$ value above the median level which is 0.648 and $d h_{i, t 2}=0$ otherwise and interact it with the intensity of SF payments, i.e. to use the $S \times h$ multiplicative term in model specification. The specification of the model that would allow the model conditioning effect of institution quality on the effect of SF payments is:

$$
\begin{aligned}
& Y_{i, t}=\delta_{0}^{\prime \prime \prime}+\delta_{1}^{\prime \prime \prime} \cdot t 2+\delta_{2}^{\prime \prime \prime} \cdot S_{i, t 2}+\delta_{3}^{\prime \prime \prime} \cdot d h_{i, t 2}+\delta_{23}^{\prime \prime \prime} \cdot S_{i, t 2} \times d h_{i, t 2} \\
& +\delta_{D i D 1}^{\prime \prime \prime} \cdot t 2 \cdot S_{i, t 2}+\delta_{D i D 2}^{\prime \prime \prime} \cdot t 2 \cdot d h_{i, t 2}+\delta_{D i D 12}^{\prime \prime \prime} \cdot t 2 \cdot S_{i, t 2} \times d h_{i, t 2}+\beta \cdot X_{i, t}+\varepsilon_{i},
\end{aligned}
$$

where $\delta^{\prime \prime \prime}{ }_{D i D 1}$ would be diff-in-diffs (effect of SF payments) for the regions with $E Q I$ below the median level and $\delta^{\prime \prime \prime}{ }_{D i D 12}$ would be the difference-of-difference-indifferences showing how the effect of SF payments in regions differs with EQI values above the median level compared with others. $\delta^{\prime \prime \prime}{ }_{D i D 1}+\delta^{\prime \prime \prime}{ }_{D i D 12}$ shows the effect of SF payments for the regions with EQI values above the median level.

\begin{tabular}{|c|c|c|c|c|c|c|c|c|c|}
\hline \multirow{3}{*}{ Variable } & \multirow{3}{*}{ Parameter } & \multicolumn{4}{|c|}{ Fixed effects estimates } & \multicolumn{4}{|c|}{ Fixed effects estimates } \\
\hline & & \multicolumn{2}{|c|}{ Financial support period } & \multicolumn{2}{|c|}{$\begin{array}{c}\text { Post-financial support } \\
\text { period }\end{array}$} & \multicolumn{2}{|c|}{ Financial support period } & \multicolumn{2}{|c|}{$\begin{array}{l}\text { Post-financial support } \\
\text { period }\end{array}$} \\
\hline & & $\operatorname{Ln}(Y)$ & $\operatorname{Ln}(\mathrm{dtaY})$ & $\operatorname{Ln}(Y)$ & $\operatorname{Ln}(\mathrm{dtaY})$ & $\operatorname{Ln}(Y)$ & $\operatorname{Ln}(\mathrm{dtaY})$ & $\operatorname{Ln}(Y)$ & $\operatorname{Ln}(\mathrm{dta} Y)$ \\
\hline Intercept & $\delta^{\prime \prime \prime}{ }_{0}$ & $\begin{array}{c}9.8458 * * * \\
(0.0363)\end{array}$ & $\begin{array}{c}9.7378 * * * \\
(0.0409)\end{array}$ & $\begin{array}{c}9.8453 * * * \\
(0.0361)\end{array}$ & $\begin{array}{c}9.7366 * * * \\
(0.0408)\end{array}$ & $\begin{array}{c}9.8193 * * * \\
(0.0023)\end{array}$ & $\begin{array}{c}9.8203 * * * \\
(0.0023)\end{array}$ & $\begin{array}{c}9.8193 * * * \\
(0.0017)\end{array}$ & $\begin{array}{c}9.8203 * * * \\
(0.0017)\end{array}$ \\
\hline$t 2$ & $\delta^{\prime \prime \prime}{ }_{1}$ & $\begin{array}{c}0.1313 * * * \\
(0.0061)\end{array}$ & $\begin{array}{c}0.2041 * * * \\
(0.0085)\end{array}$ & $\begin{array}{c}0.1271 * * \\
(0.0060)\end{array}$ & $\begin{array}{c}0.1950 * * * \\
(0.0085)\end{array}$ & $\begin{array}{c}0.2147 * * * \\
(0.0067)\end{array}$ & $\begin{array}{c}0.2223 * * \\
(0.0069)\end{array}$ & $\begin{array}{c}0.1506 * * * \\
(0.0046)\end{array}$ & $\begin{array}{c}0.1544 * * * \\
(0.0047)\end{array}$ \\
\hline$t 2 \cdot S_{i, t 2}$ & $\delta^{\prime \prime \prime}{ }_{D i D 1}$ & $\begin{array}{c}0,0004 \\
(0.0052)\end{array}$ & $\begin{array}{c}0,0057 \\
(0.0076)\end{array}$ & $\begin{array}{c}0,0017 \\
(0.0051)\end{array}$ & $\begin{array}{c}0,0081 \\
(0.0073)\end{array}$ & $\begin{array}{c}0,0029 \\
(0.0093)\end{array}$ & $\begin{array}{c}0,0039 \\
(0.0094)\end{array}$ & $\begin{array}{c}0,0032 \\
(0.0040)\end{array}$ & $\begin{array}{c}0,0012 \\
(0.0043)\end{array}$ \\
\hline$t 2 \times d h_{i, t 2}$ & $\delta^{\prime \prime \prime}{ }_{D i D 2}$ & $\begin{array}{l}0.0130 * \\
(0.0078)\end{array}$ & $\begin{array}{l}0.0171^{*} \\
(0.0096)\end{array}$ & $\begin{array}{c}0,0125 \\
(0.0078)\end{array}$ & $\begin{array}{l}0.0163 * \\
(0.0095)\end{array}$ & $\begin{array}{c}0.0259 * * * \\
(0.0059)\end{array}$ & $\begin{array}{c}0.0231 * * * \\
(0.0057)\end{array}$ & $\begin{array}{c}0.0279 * * * \\
(0.0076)\end{array}$ & $\begin{array}{c}0.0184 * * * \\
(0.0076)\end{array}$ \\
\hline$t 2 \cdot S_{i, t 2} \times d h_{i, t 2}$ & $\delta^{\prime \prime \prime} D i D 12$ & $\begin{array}{c}0,0032 \\
(0.0205)\end{array}$ & $\begin{array}{c}0,0097 \\
(0.0247)\end{array}$ & $\begin{array}{l}0.0610^{* *} \\
(0.0252)\end{array}$ & $\begin{array}{l}0.0781 * * \\
(0.0252)\end{array}$ & $\begin{array}{c}0,0283 \\
(0.0188)\end{array}$ & $\begin{array}{c}0,0158 \\
(0.0183)\end{array}$ & $\begin{array}{l}0.0342 * * \\
(0.01737)\end{array}$ & $\begin{array}{c}0.0404 * * \\
(0.0173)\end{array}$ \\
\hline$\delta^{\prime \prime \prime}{ }_{D i D 1}+$ & $\delta^{\prime \prime \prime}{ }_{D i D 12}$ & 0,0036 & 0,0154 & $0.0627 * *$ & $0.0862 * *$ & 0,0312 & 0,0197 & $0.0474 * * *$ & $0.0522 * * *$ \\
\hline$X_{i, t}$ & $\beta$ & Not est. & Not est. & Not est. & Not est. & Est. & Est. & Est. & Est. \\
\hline Sampl & size & 2498 & 2498 & 2498 & 2498 & 2498 & 2498 & 2498 & 2498 \\
\hline Within $\mathrm{R}$ & squared & 0.6722 & 0.6978 & 0.6675 & 0.6925 & 0.6694 & 0.6769 & 0.6263 & 0.6334 \\
\hline
\end{tabular}

Tab. 10. Estimates based on Eq. (8)

Notes: Robust (using HCCME) standard errors presented in parentheses. *, **, *** indicate statistical significance at the $10 \%, 5 \%$, and $1 \%$ levels, respectively 
Estimates in Tab. 10 show that over the financial support period the effect of SF payments is positive, but statistically insignificant for both groups, i.e. regions with a relatively low and high level of EQI. On the contrary, over the postfinancial support period, the effect of SF payments is positive and significant for regions with a relatively high value of $E Q I$ and insignificant for regions with a low level of $E Q I$. Estimates with time-varying effects yield slightly bigger effects compared to estimates without these. All that is consistent with our general estimates and ensures the robustness of the findings.

\section{CONCLUSIONS}

Our research shows that the institutional quality is a crucial factor that positively shapes the effect that SF payments have on diminishing disparities between regions since it may cause the intensity of SF payments as well as areas and projects where investments will be allocated. Moreover, even though the effect of SF payments is positive, there is a need for a minimum threshold level of institutional quality in the region for this effect to become statistically significant. Even more, it takes time for the positive and statistically significant effect to manifest, i.e. the estimated effect of SF payments is significant just over the postfinancial support period.

According to this conclusion, the intensity of the SF payments should be positively related to the level of institutional quality which guarantees the proper allocation and absorption of EU funds or this support should be first directed to initiatives that improve institutional quality and only after to other specific projects.

We need to emphasize that despite the fact that our research provides evidence of a general positive effect of the SF payments on diminishing regional disparities, the size of the positive effect is sensitive to the estimation method as well as to the specification of the model. Hence, this research should be considered as the first attempt to examine the institutional quality-driven effect of $\mathrm{CP}$ through SF payments in the light of disparities on the NUT3 level applying a diff -in-diffs approach.

This research is a part of the Researchers' group project on The Assessment Model of Return on the EU Regional Support (AMREUS) that has received funding from the Research Council of Lithuania under agreement No. S-MIP-17-114.

\section{REFERENCES}

ARBOLINO, R, BOFFARDI, R. (2017). The impact of institutional quality and efficient cohesion investments on economic growth evidence from Italian regions. Sustainability, 9, 1431-1432. DOI: https://doi.org/10.3390/su9081432.

AZIZ, O. G. (2018). Institutional quality and FDI inflows in Arab economies. Finance Research Letters, 25, 111-123. DOI: https://doi.org/10.1016/j.frl.2017.10.026.

BAHR, C. (2008). How does sub-national autonomy affect the effectiveness of structural funds? Kyklos, 61, 3-18. DOI: https://doi.org/10.1111/j.1467-6435.2008.00389.x.

BECKER, S. O., EGGER, P., Von EHRLICH, M. (2012). Too much of a good thing? On the growth effects of the EU's regional policy. European Economic Review, 56, 648668. DOI: https://doi.org/10.1016/j.euroecorev.2012.03.001.

BECKER, S. O., EGGER, P. H., Von EHRLICH, M. (2013). Absorptive capacity and the growth and investment effects of regional transfers: regression discontinuity design 
with heterogeneous treatment effects. American Economic Journal, 5, 29-77. DOI: https://doi.org/10.1257/pol.5.4.29.

BECKER, S., EGGER, P. H., Von EHRLICH, M. (2018). Effects of EU Regional Policy: 1989-2013. Regional Science and Urban Economics, 69, 143-152. DOI: https:// doi.org/10.1016/j.regsciurbeco.2017.12.001.

BECKER, S. O., EGGER, P., Von EHRLICH, M., FENGE, R. (2010) Going NUTS-the effect of EU structural funds on regional performance. Journal of Public Economics, 94, 578-590. DOI: https://doi.org/10.1016/j.jpubeco.2010.06.006.

BEUGELSDIJK, M., EIJFFINGER, S. C. (2005). The effectiveness of structural policy in the European Union: An empirical analysis for the EU-15 in 1995 - 2001: Journal of Common Market Studies, 43, 37-51.

BLUNDELL, R., DUNCAN, A., MEGHIR, C. (1998). Estimating labour supply responses using tax policy reforms. Econometrica, 66, 827-861. DOI: https:// doi.org/10.2307/2999575.

BOLDRIN, M., CANOVA, F. (2001). Inequality and convergence in Europe's regions: reconsidering European regional policies. Economic Policy, 32, 207-253. DOI: https:// doi.org/10.1111/1468-0327.00074.

BOUAYAD-AGHA, S., TURPIN, N., VÉDRINE, L. (2013). Fostering the development of European regions: A spatial dynamic panel data analysis of the impact of cohesion policy. Regional Studies, 47, 1573-1593. DOI: https://doi.org/10.1080/00343404. 2011.628930.

BOURDIN, S. (2015). National and regional trajectories of convergence and economic integration in Central and Eastern Europe. Canadian Journal of Regional Science, 38 $(1 / 3), 55-63$.

BOUVET, F. (2005). European Union regional policy: allocation determinants and effects on regional economic growth. Working paper, Department of Economics, University of California, Davis, CA.

BRADLEY, J., UNTIEDT, G. (2008). EU cohesion policy and "conditional" effectiveness: What do cross-section regressions tell us? Working Papers 4-2008, GEFRA - Gesellschaft fuer Finanz- und Regionalanalysen, [Online]. Available: http://www.geframuenster.org/downloads/doc/GEFRA-WP-4-2008.pdf [accessed 4 August 2019].

BUSSOLETTI, S., ESPOSTI, R. (2004). Regional convergence, structural funds and the role of agriculture in the EU. A panel-data approach. Working Papers, 220, Universita Politecnica delle Marche (I), Dipartimento di Scienze Economiche e Sociali, [Online]. Avaible: http://docs.dises.univpm.it/web/quaderni/pdf/220.pdf. [accessed 26 November 2018].

BUTKUS, M., CIBULSKIENE, D., MACIULYTE-SNIUKIENE, A., MATUZEVICIUTE, K. (2018). What is the evolution of convergence in the EU? Decomposing EU disparities up to NUTS 3 level. Sustainability, 10(5). DOI: https://doi.org/10.3390/ su10051552.

CAPPELEN, A., CASTEllaCCI, F., FAGERBERG, J., VERSPAGEN, F. (2003). The impact of EU regional support on growth and convergence in the European Union. Journal of Common Market Studies, 41, 621-644. DOI: https://doi.org/10.1111/14685965.00438.

CHARRON, N., DIJKSTRA, L., LAPUENTE, V. (2014). Regional governance matters: quality of government within European union member states. Regional Studies, 48, 68-90. DOI: https://doi.org/10.1080/00343404.2013.770141.

CHARRON, N., LAPUENTE, V., ROTHSTEIN B., eds. (2010). Measuring the quality of government and subnational variation. Report for the European Commission Directorate-General Regional Policy, Directorate Regional Policy. Quality of Quality of Government and Returns of Investment: Cohesion Expenditure in European Regions 1289 Government Institute, Department of Political Science, University of Gothenburg, Gothenburg, [Online]. Available: http://ec.europa.eu/regional_policy/sources/docgener/ studies/pdf/2010_government_1.pd. [accessed 26 November 2018]. 
CRESCENZI, R., GIUA, M. (2016). The EU cohesion policy in context: does a bottom-up approach work in all regions? Environment and Planning A: Economy and Space, 48, 2340-2357. DOI: https://doi.org/10.1177/0308518x16658291.

DALL'ERBA, S., LE GALLO, J. (2004). The impact of EU regional support on growth and employment. REAL Discussion Paper, 04-T-18.

DALL'ERBA, S., GUILLAIN, R., LE GALLO, J. (2009). Impact of structural funds on regional growth: How to reconsider a 9-year-old black box. Région et Développement, 30, 77-100.

DALL'ERBA, S., LE GALLO, J. (2008). Regional convergence and the impact of European structural funds over 1989 - 1999: A spatial econometric analysis. Papers in Regional Science, 87, 219-244. DOI: https://doi.org/10.1111/j.1435-5957.2008.00184.x.

DELLMUTH, L. M., SCHRAFF, D., STOFFEL, M. F. (2017). Distributive politics, electoral institutions and European structural and investment funding: evidence from Italy and France. Journal of Common Market Studies, 55, 275-293. DOI: https:// doi.org/10.1111/jcms. 12433 .

DIAS, J., TEBALDI, E. (2012). Institutions, human capital, and growth: The long-run institutional mechanism. Structural Change and Economic Dynamics, 23, 300-312. DOI: https://doi.org/10.1016/j.strueco.2012.04.003.

DI CATALDO, M. (2017). The impact of EU objective 1 funds on regional development: Evidence from the UK and the prospect of Brexit. Journal of Regional Science, 57, 814839. DOI: https://doi.org/10.1111/jors.12337.

DOTTI, N. F. (2016). Unwritten factors affecting structural funds: The influence of regional political behaviours on the implementation of EU cohesion policy. European Planning Studies, 24, 530-550. DOI: https://doi.org/10.1080/09654313.2015.1047328.

EBERLE, J., BRENNER, T. (2016). More bucks, more growth, more justice? The effects of regional structural funds on regional economic growth and convergence in Germany, Working Papers on Innovation and Space, 01.16, Philipps University Marburg, Department of Geography, Marburg. Available: http://hdl.handle.net/10419/147971 [accessed 26 October 2018].

EDERVEEN, S., DE GROOT, H. L. F., NAHUIS, R. (2006). Fertile soil for structural funds? A panel data analysis of the conditional effectiveness of European cohesion policy. Kyklos, 59, 17-42. DOI: https://doi.org/10.1111/j.1467-6435.2006.00318.x.

EDERVEEN, S., GORTER, J., DE MOOIJ, R., NAHUIS, R. (2002). Funds and games: The economics of European cohesion policy. CPB Special Publication, 41, [Online]. Available: https://www.cpb.nl/en/publication/funds-and-games-economics-europeancohesion-policy [accessed 26 October 2018].

EGGERT, W., Von EHRLICH, M., FENGE, R., KÖNING, G. (2007). Konvergenz- und Wachstumseffekte der europäischen Regionalpolitik in Deutschland. Perspektiven der Wirtschaftspolitik, 8, 130-146. DOI: https://doi.org/10.1111/j.1468-2516.2007.00237.x.

ESPOSTI, R., BUSSOLETTI, S. (2008). Impact of objective 1 funds on regional growth convergence in the European Union: a panel-data approach. Regional Studies, 42, 159-173. DOI: https://doi.org/10.1080/00343400601142753.

EUROPEAN COMMISSION (2017). $7^{\text {th }}$ report on economic, social and territorial cohesion, [Online]. Available: https://ec.europa.eu/regional policy/sources/docoffic/official/ reports/cohesion 7/7cr.pdf [accessed 26 October 2018].

FALK, M., SINABELL, F. (2009). A spatial econometric analysis of the regional growth and volatility in Europe. Empirica, 36, 193-207. DOI: https://doi.org/10.1007/s10663008-9078-z.

FRATESI, P., PERUCCA, G. (2014). Territorial capital and the effectiveness of cohesion policies: an assessment for CEE regions, GRINCOH. Working Paper Series, 8.05, [Online]. Available: http://www.grincoh.eu/media/serie 8 cohesion and its dimensions/grincoh wp8.05 fratesi_perucca.pdf [accessed 26 November 2018].

FRIEDRICH, R. J. (1982). In defense of multiplicative terms in multiple regression equations. American Journal of Political Science, 797-833. DOI: https://doi.org/ $10.2307 / 2110973$ 
GAGLIARDI, L., PERCOCO, M. (2017). The impact of European cohesion policy in urban and rural regions. Regional Studies, 51, 857-868. DOI: https://doi.org/ 10.1080/00343404.2016.1179384.

GARCIA-MILÀ, T., MCGUIRE, T. (2001). Do interregional transfers improve the economic performance of poor regions? The case of Spain. International Tax and Public Finance, 8, 281-295. DOI: https://doi.org/10.1023/a:1011264107134.

GIUA, M. (2017). Spatial discontinuity for the impact assessment of the EU regional policy: The case of Italian objective 1 regions. Journal of Regional Science, 57, 109-131. DOI: https://doi.org/10.1111/jors. 12300 .

GUILLAUMONT, P., CHAUVET, L. 1999. Aid and performance: A reassessment. University of Auvergne, [Online]. Available: http://publi.cerdi.org/ed/1999/1999.10.pdf [accessed 26 November 2018].

HEGERTY, S. W. (2016). Regional convergence and growth clusters in Central and Eastern Europe: An examination of sectoral-level data. Eastern European Business and Economics Journal, 2(2), 95-110.

JUDE, C., LEVIEUGE, G. (2016). Growth effect of foreign direct investment in developping economies: The role of institutional quality. The World Economy, 40, 715-742.

KHORDAGUI, N. H., SALEH, G. (2013). FDI and absorptive capacity in emerging economies. Middle Eastern and African Economies, 15, 141-172. DOI: https://doi.org/ 10.1504/ijbg.2016.074486.

KUTAN, A. M., YIGIT, T. M. (2007). European integration, productivity growth and real convergence. European Economic Review, 51, 1370-1395. DOI: https:// doi.org/10.1016/j.euroecorev.2006.11.001.

KYRIACOU, A. P., ROCA-SAGALÉS, O. (2012). The impact of EU structural funds on regional disparities within member states. Environment and Planning C: Politics and Space, 30, 267-281. DOI: https://doi.org/10.1068/c11140r.

LE GALLO, J., DALL'ERBA, S., GUILLAIN, R. (2011). The local versus global dilemma of the effects of structural funds. Growth Change, 42, 466-490. DOI: https:// doi.org/10.1111/j.1468-2257.2011.00564.x.

LLUSSÁ, F., LOPES, J., M. (2011). Regional growth in Europe: The role of European and national policies. Universidade Nova de Lisboa, Faculdade de Economia, [Online]. Available: https://run.unl.pt/bitstream/10362/11171/1/wp554.pdf [accessed 26 November 2018].

MARTIN, R. (2003). The impact of the EU's structural and cohesion funds on real convergence in the EU. NBP Conference „Potential Output and Barriers to Growth”. Zalesie Górne, [Online]. Available: http://pki.nbp.pl/konferencje/zalesie/pdf/martin.pdf [accessed 20 November 2018].

MAYNOU, L., SAEZ, M., KYRIACOU, A., BACARIA, J. (2016). The impact of structural and cohesion funds on Eurozone convergence, 1990 - 2010. Regional Studies, 50, 1127-1139. DOI: https://doi.org/10.1080/00343404.2014.965137.

MOHL, P., HAGEN, T. (2010). Does EU structural funds promote regional growth? New evidence from various panel data approaches. Regional Science and Urban Economics, 40, 353-365. DOI: https://doi.org/10.1016/j.regsciurbeco.2010.03.005.

NOORBAKHSH, F., POLINI, A., YOUSSEF, A. (2001). Human capital and FDI inflows to developing countries: New empirical evidence. World Development, 29, 1593-1610. DOI: https://doi.org/10.1016/S0305-750X(01)00054-7.

PELlEGRINI, G., BUSILlO, T., MUCCIGROSSO, T., TAROLA, O., TERRIBILE, F. (2013). Measuring the Impact of the European regional policy on economic growth: a regression discontinuity design approach. Papers in Regional Science, 92, 217-233. DOI: https://doi.org/10.1111/j.1435-5957.2012.00459.x.

PELLEGRINI, G., CERQUA, A. (2016). Measuring the impact of intensity of treatment using RDD and covariates: the case of Structural Funds. 57th RSA Annual Conference, Bocconi University, 20-22 October, 2016, [Online]. Available: http://www.siecon.org / online/wp-content/uploads/2016/09/PELLEGRINI.pdf [accessed 20 November 2018]. 
PINHO, C., VARUM, C., ANTUNES, M. (2015). Structural funds and European regional growth: Comparison of effects among different programming periods. European Planning Studies, 23, 1302-1326. DOI: https://doi.org/10.1080/09654313.2014.928674.

PERCOCO, M. (2017) Impact of European cohesion policy on regional growth: Does local economic structure matter? Regional Studies, 51, 833-843. DOI: https://doi.org/ 10.1080/00343404.2016.1213382.

PIĘTAK, L. (2018) Did structural funds affect economic growth and convergence across regions? Spanish case in the years 1989 - 2016. INE PAN Working Paper Series, 44, [Online]. Available: http://inepan.pl/wp-content/uploads/2016/07/working-papers-44Hiszpania-Pietak.pdf [accessed 20 November 2018].

PUIGCERVER-PENALVER, M. C. (2007). The impact of structural funds policy on European regions' growth. A theoretical and empirical approach. The European Journal of Comparative Economics, 4, 179-208.

RODRÍGUEZ-POSE, A., GARCILAZO, E. (2015) Quality of government and the returns of investment: examining the impact of cohesion expenditure in European regions. Regional Studies, 49, 1274-1290. DOI: https://doi.org/10.1080/00343404.2015.1007933.

SOUKIAZIS, E., ANTUNES, M. (2006). Two speed regional convergence in Portugal and the importance of structural funds on growth. Ekonomia, 9, 222-241.

TSIONAS, M., SAKKAS, S., BALTAS, N. C. (2014). Regional convergence in Greece (1995 - 2005): A dynamic panel perspective. Economics Research International, 2014, 1-6. DOI: https://doi.org/10.1155/2014/385038.

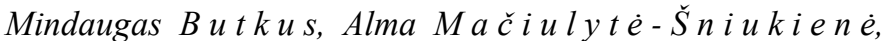 \\ Kristina Matuzeviči uté
}

\title{
ÚLOHA INŠTITÚCIÍ PRI FORMOVANÍ GEOGRAFICKÉHO ROZLOŽENIA ROZVOJOVÝCH DISPARÍT V EÚ
}

Analýza doterajších príspevkov ukázala, že existuje len niekol'ko štúdií, ktoré skúmajú vplyv transferov štrukturálnych fondov Európskej únie (ŠF) na regionálne rozdiely, napriek skutočnosti, že zníženie teritoriálnych disparít z hl'adiska ich úrovne rozvoja je konečným ciel'om kohéznej politiky. Analýza literatúry tiež ukazuje, že dôraz sa kladie na sledovanie údajov na úrovni regiónov NUTS 1 a 2 , ked'že väčšina platieb ŠF je zameraná na riešenie problémov vznikajúcich v regiónoch NUTS 2 . Nie je preto jasné, aký je vplyv platieb zo ŠF na regionálne disparity, a to najmä na úrovni desagregácie NUTS 3.

Štúdium príspevkov, ktoré sa zameriavajú na faktory vplyvu platieb zo ŠF, ukazuje, že potenciálne heterogénne účinky v rámci regiónov by sa mohli vyskytnút' v dôsledku 1) inštitucionálnej kvality/efektívnosti, 2) ekonomickej otvorenosti, 3) l’udského kapitálu/ vzdelania, 4) mikroekonomického a makroekonomického prostredia a mnohých d'alších faktorov. Je preto dôležité, aby model určený na hodnotenie vplyvu platieb zo SF na regionálne rozdiely bol schopný brat' do úvahy podmienečné faktory, ktoré môžu tento účinok zvyšovat' alebo zmierňovat'. Pri diskusiách o faktoroch, ktoré podmieňujú účinok platieb $\mathrm{SF}$, je možné dospiet' $\mathrm{k}$ záveru, že všetky z nich sú vzájomne prepojené. Ak berieme do úvahy, že všetky faktory závisia od inštitucionálnej kvality alebo s ňou aspoň úzko súvisia, možno túto skutočnost' považovat' za hlavnú podmienku vplyvu prostriedkov zo ŠF.

Naša navrhovaná stratégia hodnotenia pre odhad vplyvu platieb zo ŠF dopíňa novovznikajúci prúd v odbornej literatúre založený na kvázi experimentálnom prístupe odhadov rozdielu v rozdieloch (diff-in-diffs estimator). Poukazuje na dôležitost' zváženia podmienených účinkov a podmienečného významu týchto účinkov pri použití interaktívnych rovníc $\mathrm{s}$ multiplikatívnymi podmienkami na modelovanie faktorov, ktoré podmieňujú účinok platieb zo ŠF.

Údaje použité na empirickú analýzu sú na úrovni NUTS 3 berú do úvahy vplyv platieb zo ŠF v programovom období 2000 - 2006. Pri odhadovaní vplyvu platieb ŚF sme použili 
odhad rozdielu v rozdieloch, pričom sa porovnávajú obdobia finančnej podpory (2000 2006) a obdobia po finančnej podpore $(2007$ - 2011) s obdobím pred finančnou podporou (1995 - 1999), ako aj HDP na obyvatel'a upravený podl'a rozdielových trendov.

Výsledky odhadov ukazujú, že kvalita inštitúcií je rozhodujúcim faktorom, ktorý ovplyvňuje vel'kost', ako aj význam vplyvu platieb zo SF na regionálne rozdiely. Dospeli sme k záverom, že v období finančnej podpory mali platby ŠF pozitívny štatisticky významný vplyv na znižovanie regionálnych disparít len vo vel'mi úzkom rozmedzí hodnôt inštitucionálnej kvality zameraných na priemernú hodnotu. Odhady na obdobie po finančnej podpore poukazujú na pozitívny účinok transferov ŠF, ako aj skutočnost', že existuje minimálna prahová úroveň inštitucionálnej kvality, aby sa tento účinok stal štatisticky významným. 